\title{
Article \\ Chemical Vapor Deposited Mixed Metal Halide Perovskite Thin Films
}

\author{
Siphesihle Siphamandla Magubane ${ }^{1, * \mathbb{D}}$, Christopher Joseph Arendse ${ }^{1, * \mathbb{D}}$, Siphelo Ngqoloda ${ }^{1}(\mathbb{D}$, \\ Franscious Cummings ${ }^{1} \mathbb{D}$, Christopher Mtshali ${ }^{2}$ and Amogelang Sylvester Bolokang ${ }^{1,3}$
}

1 Department of Physics and Astronomy, University of the Western Cape, Private Bag X17, Bellville 7535, South Africa; sngqoloda@uwc.ac.za (S.N.); fcummings@uwc.ac.za (F.C.); sbolokang@csir.co.za (A.S.B.)

2 iThemba LABS, National Research Foundation, Somerset West 7129, South Africa; mtshali@tlabs.ac.za

3 CSIR Material Science \& Manufacturing, Advanced Materials and Engineering, Meiring Naude Road, Pretoria 0001, South Africa

* Correspondence: smagubane@uwc.ac.za (S.S.M.); cjarendse@uwc.ac.za (C.J.A.); Tel.: +27-21-959-3473 (C.J.A.)

check for updates

Citation: Magubane, S.S.; Arendse, C.J.; Ngqoloda, S.; Cummings, F.; Mtshali, C.; Bolokang, A.S. Chemical Vapor Deposited Mixed Metal Halide Perovskite Thin Films. Materials 2021, 14, 3526. https://doi.org/10.3390/ ma14133526

Academic Editor: Victor Ralchenko

Received: 11 May 2021

Accepted: 18 June 2021

Published: 24 June 2021

Publisher's Note: MDPI stays neutral with regard to jurisdictional claims in published maps and institutional affiliations.

Copyright: (c) 2021 by the authors. Licensee MDPI, Basel, Switzerland. This article is an open access article distributed under the terms and conditions of the Creative Commons Attribution (CC BY) license (https:// creativecommons.org/licenses/by/ $4.0 /)$.

\begin{abstract}
In this article, we used a two-step chemical vapor deposition (CVD) method to synthesize methylammonium lead-tin triiodide perovskite films, $\mathrm{MAPb}_{1-\mathrm{x}} \mathrm{Sn}_{\mathrm{x}} \mathrm{I}_{3}$, with $\mathrm{x}$ varying from 0 to 1 . We successfully controlled the concentration of $\mathrm{Sn}$ in the perovskite films and used Rutherford backscattering spectroscopy (RBS) to quantify the composition of the precursor films for conversion into perovskite films. According to the RBS results, increasing the $\mathrm{SnCl}_{2}$ source amount in the reaction chamber translate into an increase in Sn concentration in the films. The crystal structure and the optical properties of perovskite films were examined by X-ray diffraction (XRD) and UV-Vis spectrometry. All the perovskite films depicted similar XRD patterns corresponding to a tetragonal structure with $\mathrm{I} 4 \mathrm{~cm}$ space group despite the precursor films having different crystal structures. The increasing concentration of $\mathrm{Sn}$ in the perovskite films linearly decreased the unit volume from about 988.4 $\AA^{3}$ for $\mathrm{MAPbI}_{3}$ to about $983.3 \AA^{3}$ for $\mathrm{MAPb}_{0 \cdot 39} \mathrm{Sn}_{0 \cdot 61} \mathrm{I}_{3}$, which consequently influenced the optical properties of the films manifested by the decrease in energy bandgap $\left(E_{g}\right)$ and an increase in the disorder in the band gap. The SEM micrographs depicted improvements in the grain size $(0.3-1 \mu \mathrm{m})$ and surface coverage of the perovskite films compared with the precursor films.
\end{abstract}

Keywords: mixed metal-mixed halide perovskites; chemical vapour deposition (CVD); elemental stoichiometry; structure-property relationship

\section{Introduction}

Three-dimensional (3-D) organo-lead halide perovskites, which form a perovskite structure of $\mathrm{ABX}_{3}$, have received tremendous research interest over the past decade [1]. As a result, we have seen tremendous progress in the solar cell (SC) performance from $3.8 \%$ to $25.5 \%$ power conversion efficiency (PCE) of these lead-based perovskite SCs. This is due to their high optical absorption coefficients, high charge carrier mobilities, long charge carrier diffusion lengths, low exciton binding energy, bandgap tunability, and low-temperature solution processability [2-10]. Despite this overwhelming development, considering the nature of the solar absorption spectrum, the maximum theoretical efficiency can be achieved in a single junction device with an optimum energy bandgap $\left(E_{g}\right)$ of about 1.1 to $1.3 \mathrm{eV}$ [11]. Broadening the range of solar absorption to the near-infrared (IR) region could further enhance the performance of perovskite SCs [12]. Therefore, the relatively wide $E_{g}(1.5-2.2 \mathrm{eV})$ of organo-lead halide perovskite dramatically limits the sensitivity of the film in the IR region of the solar spectrum [13]. Another major drawback that is associated with lead-based perovskites is the toxicity of the lead $(\mathrm{Pb})$ element and its compounds, which pose threats to the environment and human well-being, thus restricting the commercialization of Pb-based perovskite solar cells (PSCs) [7,14-18]. 
The challenges that are associated with $\mathrm{Pb}$-based perovskites have sparked research interest in the partial and complete replacement of $\mathrm{Pb}$ with tin $(\mathrm{Sn})$ in the perovskite structure, not only to reduce the toxic $\mathrm{Pb}$ but also to extend the absorption range to above $960 \mathrm{~nm}$ wavelengths, i.e., below $1.3 \mathrm{eV}$ [19-25]. On one hand, a complete replacement of $\mathrm{Pb}$ seems to be improbable at this point due to the low PCE of Sn-based perovskite SCs that is driven by the rapid crystallization of Sn-based perovskite, making the film growth control to be a challenge [26-28]. Moreover, Sn-perovskite films are very unstable compared to pure $\mathrm{Pb}$-based perovskites $[24,25,27]$. This instability is due to the easy oxidation of $\mathrm{Sn}^{2+}$ to $\mathrm{Sn}^{4+}$ that causes $\mathrm{Sn}$ vacancies in the film, thus promoting non-radiative recombination, which leads to reduced charge carrier lifetimes in the PSCs [29,30]. On the other hand, tremendous efficiency improvements and various discoveries have been made in the low-bandgap (1.17-1.1.38 eV) Pb-Sn PSCs [31-34].

The technique that is mostly employed to deposit the low-bandgap mixed $\mathrm{Pb}$-Sn halide perovskite is one-step spin-coating with antisolvent treatment followed by annealing at about $100{ }^{\circ} \mathrm{C}$ for crystallization [31]. Different ratios of solvents, i.e., Dimethylformamide (DMF) and Dimethyl sulfoxide (DMSO), have been explored and different organic cations such as methylammonium (MA), formamidinium (FA), cesium (Cs), and halides like iodine $(\mathrm{I})$, bromine $(\mathrm{Br})$, chlorine $(\mathrm{Cl})$, or a combination of these halides have been investigated [30,35-43]. It has been observed that uniform, large-grained, and pinhole-free films with high surface coverage are requirements for the high performance of Sn-based PSCs [31]. However, there seems to be a consensus that the control of crystal growth becomes complicated as the proportion of $\mathrm{Sn}$ increases in the perovskite structure $[32,44,45]$. The crystal structure of methylammonium lead-tin triiodide $\left(\mathrm{MAPb}_{1-\mathrm{x}} \mathrm{Sn}_{\mathrm{x}} \mathrm{I}_{3}\right)$ perovskites transition from tetragonal phase (space group $14 \mathrm{~cm}$ ) to pseudo-cubic phase (space group $P 4 \mathrm{~mm}$ ) when $x$ nears 0.5 (for $x$ ranging from 0 to 1) [31]. During this transition the valence band (VB) and the conduction band (CB) undergo an energy shift from -5.45 and $-3.90 \mathrm{eV}$ (for $x=0$ ) to -4.73 and $-3.63 \mathrm{eV}$ (for $x=1$ ), respectively [28,31,33,46-48]. These changes are attributed to the perovskite crystal lattice compression and distortion as a result of increased Sn incorporation [49-52].

Additional efforts, such as the incorporation of additives like halogens and thiocyanate $(\mathrm{SCN})$ series in the perovskite structure, film surface passivation, and interface engineering aiming at reducing grain boundaries and charge scattering thereby extending the charge carrier lifetimes, and increasing the charge diffusion lengths, have all been explored. Halide doping, including $\mathrm{Cl}$ or $\mathrm{Br}$, is another effective strategy to enhance the film quality of the mixed $\mathrm{Pb}-\mathrm{Sn}$ perovskites $[49,53]$. This allows the precursor solution to convert to a perovskite consisting of intermixing of $\mathrm{Br} / \mathrm{Cl}$ and iodine in the lattice, thereby reducing Sn and iodine vacancies in the film $[49,53]$. Other researchers have proved that similarly to halide doping, the addition of antioxidants and ascorbic acids such as tin fluoride $\left(\mathrm{SnF}_{2}\right)$, tin sulfide $(\mathrm{SnS})$, quaternary ammonium halide $\left(\mathrm{Me}_{4} \mathrm{NBr}\right)$, tetramethylammonium iodide $\left(\mathrm{Me}_{4} \mathrm{NI}\right)$, methylammonium bromide $(\mathrm{MABr})$, lead thiocyanate $\left(\mathrm{Pb}(\mathrm{SCN})_{2}\right)$, and other thiocyanate $(\mathrm{SCN})$ salts can improve the perovskite film quality [31]. They ascribed this to reductive additives that do not only prevent $\mathrm{Sn}^{2+}$ oxidation, but also promote the crystallization growth through strong coordination between $\mathrm{PbI}_{2} / \mathrm{SnI}_{2}$ and an organic cation or a combination of organic cations which allows the complete interaction and conversion of metal halides into perovskite [53-61].

Attempts to improve the charge diffusion length, including but not limited to the incorporation of cadmium iodide (CdI) and/or metallic $\mathrm{Sn}$ in the low bandgap $\mathrm{Pb}-\mathrm{Sn}$ perovskite, have also been explored [30,59,60]. This reduces the free hole concentration and electron density, which leads to an improved diffusion length of up to $3 \mu \mathrm{m}$ [31]. Other attempts, such as the deposition of ultrathin bulk-heterojunction (BHJ) organic semiconductor layer as an intermediary between the hole transport layer (HTL) and the mixed low bandgap perovskite to minimize the energy loss by reducing energy level mismatch and passivating defects in the HTL/perovskite interface have been reported [58,61-63]. 
The need to produce stable perovskite films that will withstand exposure to outdoor conditions without introducing morphological and structural changes that consequently affect the electronic properties of the films, remains. This article, therefore, aims to optimize and establish the processing conditions to synthesize uniform and stable low bandgap mixed $\mathrm{Pb}-\mathrm{Sn}$ perovskite films that exhibit homogenous elemental distribution using a chemical vapor deposition (CVD) technique. We have successfully controlled the concentration of $\mathrm{Sn}$ in the perovskite structure and then examined the structure-property relationship of these perovskite films in relation to the deposition technique. The technique is divided into two steps that include (i) the co-evaporation and deposition of tin chloride-lead iodide $\left(\mathrm{SnCl}_{2}-\mathrm{PbI}_{2}\right)$ compound films, followed by (ii) the conversion of these compound films into perovskite through exposure to methylammonium iodide (MAI) vapor [64]. The two-step deposition technique is employed because it promises a better understanding of the formation mechanism of the perovskite films through controlling the precursor films deposition parameters and the conversion parameters, independently [62,63]. Also, the CVD method avoids the use of solvents to dissolve the precursor chemicals, which results in highly stable, uniform, largely grained, and pin-hole free perovskite films [62,63]. This is due to the low pressure (1 mbar) and inert environment in which the processing/deposition takes place. In terms of large-scale production and reproducibility, the CVD technique is the strongest contender over the cost-efficient solution-processed perovskites, because it is well established in the semiconductor industry especially in silicon-based research [64,65].

\section{Materials and Methods}

\subsection{Precursor Thin Films Deposition}

Mixed $\mathrm{SnCl}_{2}-\mathrm{PbI}_{2}$ precursor films were deposited on $1.5 \times 2 \mathrm{~cm}^{2}$ corning glass substrates that were cleaned via sonication in boiling hellmanex solution and isopropanol for $15 \mathrm{~min}$ each in an ultrasonic bath. After that, the substrates were rinsed in boiling deionized (DI) water and then dried with a nitrogen $\left(\mathrm{N}_{2}\right)$ gun. The deposition system that was used is composed of a horizontal quartz tube enclosed with the three-independent temperature-controlled zone furnace (Brother XD 1600MT Furnace Co., LTD, Zhengzhou, China) [64]. All the materials were purchased from Sigma Aldrich (St. Louis, MO, USA) and were used as obtained without any further purification. A ceramic boat containing a mixture of different powder amounts of $98 \%$ purity $\mathrm{SnCl}_{2}$ (i.e., $2.5,5,10$, and $15 \mathrm{mg}$ ) and $20 \mathrm{mg}$ of $99.9 \% \mathrm{PbI}_{2}$ was placed in the 1st zone while the substrates were placed in the 2nd zone at about 16-20 cm away from the source boat [64]. The tube of the furnace was then sealed and pumped down to a base pressure of 0.04 mbar. Next, the tube was purged with $\mathrm{N}_{2}$ gas at a rate of $200 \mathrm{sccm}$ (i.e., standard cubic centimeters per minute) to flush away all form of contaminations pre-existed in the tube. Then, the source boat was heated to a temperature of $380{ }^{\circ} \mathrm{C}$ while flowing $\mathrm{N}_{2}$ gas at a rate of $500 \mathrm{sccm}$ to direct the vapor towards the substrates. The deposition pressure was between 2.5 to $3 \mathrm{mbar}$ and the duration was set for $20 \mathrm{~min}$, after which the sources were evaporated completely. For comparison purposes, pure $\mathrm{PbI}_{2}$ and $\mathrm{SnCl}_{2}$ films were deposited in a similar manner except that the evaporation temperature was $270{ }^{\circ} \mathrm{C}$ for the $\mathrm{SnCl}_{2}$ source and $380{ }^{\circ} \mathrm{C}$ for $\mathrm{PbI}_{2}$.

\subsection{Precursor Films Conversion into Perovskites}

The as-deposited precursor films were converted into perovskite films through exposure to MAI $\left(\mathrm{CH}_{3} \mathrm{NH}_{3} \mathrm{I}\right)$ vapor in the same CVD system [64]. A ceramic boat containing $60 \mathrm{mg}$ of MAI (Dyesol) was placed at the center of zone 1 while the precursor films, i.e., $\mathrm{PbI}_{2}, \mathrm{SnCl}_{2}$, and mixed $\mathrm{SnCl}_{2}-\mathrm{PbI}_{2}$ compound films were placed in the second zone, downstream, at about $18 \mathrm{~cm}$ away from the source [64]. The tube of the furnace was then sealed and pumped down to also a base pressure of 0.04 mbar. Next, the tube was purged with $\mathrm{N}_{2}$ gas at a rate of $200 \mathrm{sccm}$. Then, the MAI was heated to a temperature of $180^{\circ} \mathrm{C}$ while the precursor films were heated and maintained at about $85{ }^{\circ} \mathrm{C}$ while a $100 \mathrm{sccm}$ flow rate of $\mathrm{N}_{2}$ gas was maintained to direct the MAI vapor towards the precursor films. The conversion pressure was maintained at about $0.9 \mathrm{mbar}$ and the duration was set for $50 \mathrm{~min}$. 


\subsection{Characterisation Methods}

A Zeiss Auriga (Carl Zeiss Jena GmbH, Jena, Germany) field emission gun scanning electron microscope (FEG-SEM) equipped with an energy dispersive $\mathrm{X}$-ray detector, was operated at an acceleration voltage of $5 \mathrm{kV}$ to probe the surface morphology and the elemental composition of the precursor films. The thickness and the roughness of the films were measured using a Dektak 6M stylus profilometer (Veeco Instruments, Inc., Tucson, AZ, USA). The depth profile and the composition of the films were further examined through Rutherford Backscattering Spectrometry (RBS) (Cape Town, South Africa) using an ion emanating from 3 MV Tandetron accelerator (High Voltage Engineering Europa BV, Amersfoort, Netherlands) hosted at iThemba Laboratory for Accelerator-Based Science (Cape Town, South Africa). A $3.05 \mathrm{MeV} \mathrm{He}^{++}$ion beam was used, where the average current of $60 \mathrm{nA}$ and the total collected charge of $40 \mu \mathrm{C}$ were maintained for all samples. A Bruker AXS D8 diffractometer (Bruker, Karlsruhe, Germany) with an irradiation line $\mathrm{Ka} 1$ of copper $(\mathrm{kCuKa} 1=1.5406 \AA)$ operating at a voltage of $40 \mathrm{kV}$ and a current of $35 \mathrm{~mA}$ was used for the investigation of the crystal structure and phase composition of the films. During this experiment, the samples were scanned over a $2 \theta$-range of $10^{\circ}$ to $100^{\circ}$, with a step size of $0.026^{\circ}$.

\section{Results and Discussions}

\subsection{Mixed $\mathrm{SnCl}_{2}-\mathrm{PbI}_{2}$ Precursor Films}

\subsubsection{Surface Morphology}

Throughout the discussion of the precursor films, samples will be referred to according to the $\mathrm{SnCl}_{2}: \mathrm{PbI}_{2}$ mass ratio used during the preparation of these precursor films. It is observed from the SEM micrographs in Figure $1 \mathrm{a}$ that $\mathrm{PbI}_{2}$ form a highly compact film composed of large grains that are tightly packed across the whole substrate. This behavior is consistent with that observed from the literature [66-68]. From Figure 1b, it is observed that $\mathrm{SnCl}_{2}$ forms randomly shaped, distinguishable islands with clearly defined boundaries. Furthermore, the $\mathrm{SnCl}_{2}$ forms clusters or agglomerates that are circled in red in Figure $1 \mathrm{~b}$. This SEM micrograph is different from those obtained by $\mathrm{R}$. Felix et al. for $\mathrm{SnCl}_{2}$ films that were deposited using a 4-pocket evaporator attached to the ultra-high vacuum (UHV) deposition chamber [69]. Their results suggested that the growth mechanism of the $\mathrm{SnCl}_{2}$ film is divided into two-part; the lateral formation of the seeding layer followed by the vertical growth of the $\mathrm{SnCl}_{2}$ islands [69]. This suggests that our film might have reacted with moisture to form impurities such as tin oxide or hydrogen chloride since their films were prepared and studied in the system without exposure to ambient air conditions.

Figure $1 \mathrm{c}, \mathrm{d}$ shows the SEM micrographs of mixed $\mathrm{PbI}_{2}-\mathrm{SnCl}_{2}$ compound films composed of different amount of $\mathrm{SnCl}_{2}$ (i.e., $2.5 \mathrm{mg}, 5 \mathrm{mg}$, $10 \mathrm{mg}$, and $15 \mathrm{mg}$ mixed with $20 \mathrm{mg}$ of $\left.\mathrm{PbI}_{2}\right)$. Overall, it is observed that the presence of $\mathrm{PbI}_{2}$ improves the quality of the film of $\mathrm{SnCl}_{2}$. Figure 1c $((2.5: 20) \mathrm{mg})$ depicts a film composed of clearly defined grains with grain sizes in the range between $200-400 \mathrm{~nm}$ and a high density of small-sized pores. Increasing the amount of $\mathrm{SnCl}_{2}$ to $5 \mathrm{mg}$ in the film results in the coalescing of the small grains thereby forming larger grains. This sample still possesses low surface coverage due to the increase in the size of pores (Figure 1d). Figure 1e, $\mathrm{f}$ show that further increasing the amount of $\mathrm{SnCl}_{2}$ in the mixed metal-halide compound results in the deterioration of the quality of the films, hence, the observed disordered films with a larger number of pores that extend through the film to the substrate, which resulted in poor surface coverage. The thickness evolution of the compound films upon the increase of $\mathrm{SnCl}_{2}$ amount was measured using Dektak profilometer and plotted in Figure S2a in the supporting information (Supplementary Materials). It is observed from Figure S1a that the thickness of the films increases linearly as the amount of $\mathrm{SnCl}_{2}$ that was added in the crucible increases. 

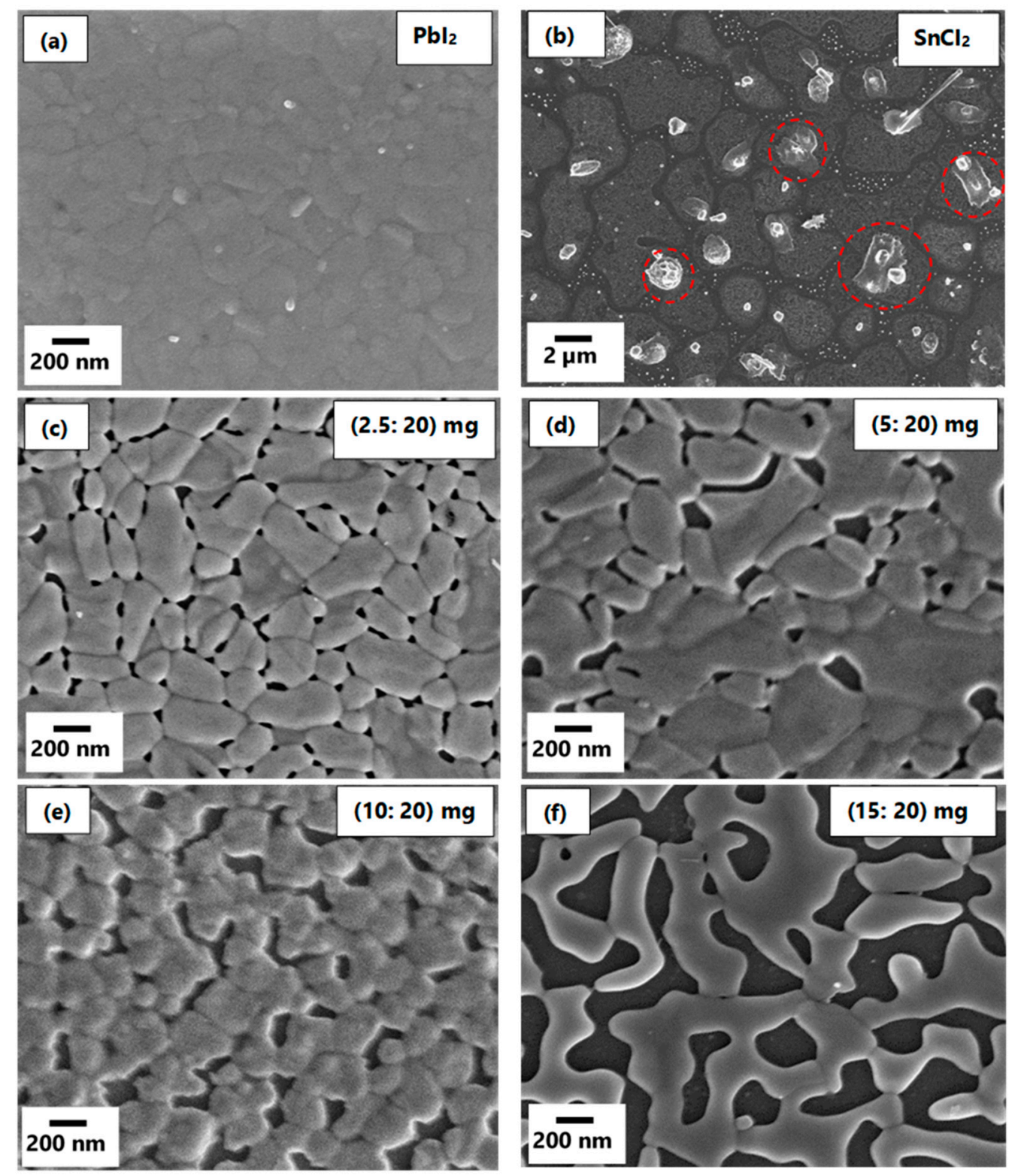

Figure 1. SEM micrographs of (a) $\mathrm{PbI}_{2}$ film, (b) $\mathrm{SnCl}_{2}$ films and (c-f) mixed metal -halide thin films.

\subsubsection{Rutherford Backscattering Spectrometry (RBS)}

RBS was used for the determination of the stoichiometry and the depth profiles of the films. Figure 2a shows the experimental RBS spectra of $\mathrm{PbI}_{2}$ and mixed $\mathrm{SnCl}_{2}-$ $\mathrm{PbI}_{2}$ compound thin films. Energy X-ray dispersive spectroscopy (EDS) data, not shown, was used for initial composition as required by SIMNRA software to begin the fitting process; with the simulated RBS spectra provided in Figure $\mathrm{S} 2$. The $\mathrm{PbI}_{2}$ film (black) shows two peaks of alpha particles backscattered from $\mathrm{Pb}$ and I atoms with surface energies of $2826.9 \mathrm{keV}$ and $2694.2 \mathrm{keV}$, respectively. Although this is a single-layered film, the $\mathrm{Pb}$ peak appears at higher energy as compared to the I peak due to the difference in their atomic masses. This spectrum (i.e., $\mathrm{PbI}_{2}$ film) could be simulated using two layers with a total thickness and the average stoichiometry of $3.61 \times 10^{17}$ atoms $/ \mathrm{cm}^{2}$ and $\mathrm{Pb}_{0.35} \mathrm{I}_{0.65}$, respectively. Refer to Table 1 below for layer-by-layer details. The stoichiometry of the $\mathrm{PbI}_{2}$ film reported in this work corresponds to that reported by Popov et al. [70] and Tsevas et al. [71]. 

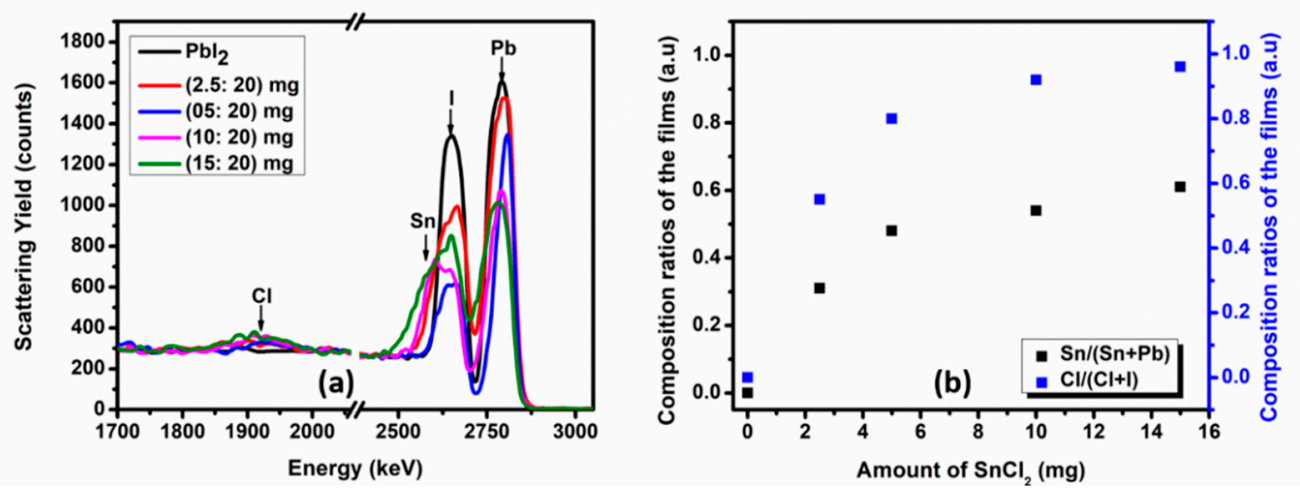

Figure 2. (a) The experimental RBS spectra of $\mathrm{PbI}_{2}$ and mixed $\mathrm{SnCl}_{2}-\mathrm{PbI}_{2}$ compound thin films, and (b) the compositional ratios of $\mathrm{Sn} /(\mathrm{Sn}+\mathrm{Pb})$ and $\mathrm{Cl} /(\mathrm{Cl}+\mathrm{I})$ in the precursor films.

Table 1. Stoichiometry obtained from the simulated RBS spectra.

\begin{tabular}{ccccccc}
\hline Sample ID & Layer Depth $\left(\times \mathbf{1 0}^{\mathbf{1 7}}\right.$ Atoms $\left./ \mathbf{c m}^{\mathbf{2}}\right)$ & $\mathbf{C l}$ & $\mathbf{S n}$ & $\mathbf{I}$ & $\mathbf{P b}$ \\
\hline \multirow{2}{*}{ Lead iodide } & L1 & 1.94 & - & - & 0.65 & 0.35 \\
& L2 & 1.67 & - & - & 0.64 & 0.36 \\
$(2.5: 20) \mathrm{mg}$ & L1 & 2.28 & 0.18 & 0.07 & 0.44 & 0.31 \\
& L2 & 1.94 & 0.54 & 0.14 & 0.16 & 0.10 \\
$(5: 20) \mathrm{mg}$ & L1 & 2.94 & 0.42 & 0.04 & 0.20 & 0.34 \\
& L2 & 0.95 & 0.36 & 0.31 & 0.03 & 0.29 \\
& L3 & 0.70 & 0.52 & 0.29 & 0.11 & 0.07 \\
$(10: 20) \mathrm{mg}$ & L1 & 1.40 & 0.48 & 0.15 & 0.03 & 0.34 \\
& L2 & 1.51 & 0.38 & 0.33 & 0.05 & 0.24 \\
& L3 & 2.03 & 0.50 & 0.34 & 0.04 & 0.12 \\
$(15: 20) \mathrm{mg}$ & L1 & 2.25 & 0.41 & 0.21 & 0.04 & 0.34 \\
& L2 & 1.81 & 0.47 & 0.34 & 0.02 & 0.17 \\
& L3 & 1.95 & 0.57 & 0.36 & 0.01 & 0.06 \\
\hline
\end{tabular}

It can be observed from Figure 2a that mixing $\mathrm{SnCl}_{2}$ and $\mathrm{PbI}_{2}$ for the formation of compound films results; (i) in the quenching of the $\mathrm{Pb}$ peak intensity, (ii) peak broadening toward lower energies of iodine peak because of Sn peak with a surface energy of $2694.2 \mathrm{keV}$, which is close to the ions scattered from iodine, (iii) the development of $\mathrm{Cl}$ peak with a surface energy of $1952.9 \mathrm{keV}$. The addition of more $\mathrm{SnCl}_{2}$ in the mixed $\mathrm{SnCl}_{2}-\mathrm{PbI}_{2}$ compound films results in the progressive quenching of the $\mathrm{Pb}$ peak intensity and Sn/I peak broadening, as can be seen from Figure 2a. The quenching of scattering yield from the $\mathrm{Pb}$ atoms (especially at lower energies) as the amount of $\mathrm{SnCl}_{2}$ is increased implies that there is a spontaneous reaction between $\mathrm{SnCl}_{2}$ and $\mathrm{PbI}_{2}$ during the deposition, which might have been facilitated by the diffusion of surface atoms toward the substrate and/or the migration of bottom atoms toward the surface of the films. The Sn/I peak broadening and increasing intensity of $\mathrm{Cl}$ peaks indicate the progressive increase of $\mathrm{Sn}$ and $\mathrm{Cl}$ concentrations within the mixed $\mathrm{SnCl}_{2}-\mathrm{PbI}_{2}$ compound films.

Since the concentration of $\mathrm{Sn}$ increases upon the addition of $\mathrm{SnCl}_{2}$, the quenching of $\mathrm{Sn} / \mathrm{I}$ peaks suggest that $\mathrm{Cl}$ atoms replace some I atoms in the mixed $\mathrm{SnCl}_{2}-\mathrm{PbI}_{2}$ compound films. These mixed $\mathrm{SnCl}_{2}-\mathrm{PbI}_{2}$ compound films that were deposited using different amount of $\mathrm{SnCl}_{2}$, i.e., $2.5 \mathrm{mg}$ (red), $5 \mathrm{mg}$ (blue), $10 \mathrm{mg}$ (magenta), and $15 \mathrm{mg}$ (green) mixed with $20 \mathrm{mg}$ of $\mathrm{PbI}_{2}$ were simulated using three layers with a total thickness $\left(\times 10^{17}\right.$ atoms $\left./ \mathrm{cm}^{2}\right)$ and average stoichiometry of $4.22 \& \mathrm{~Pb}_{0.24} \mathrm{Sn}_{0.11} \mathrm{I}_{0.30} \mathrm{Cl}_{0.36}, 4.59 \& \mathrm{~Pb}_{0.23} \mathrm{Sn}_{0.21} \mathrm{I}_{0.11} \mathrm{Cl}_{0.43}, 4.94$ $\& \mathrm{~Pb}_{0.23} \mathrm{Sn}_{0.27} \mathrm{I}_{0.04} \mathrm{Cl}_{0.45}$ and $6.01 \& \mathrm{~Pb}_{0.19} \mathrm{Sn}_{0.30} \mathrm{I}_{0.02} \mathrm{Cl}_{0.48}$, respectively. Refer to Table 1 for the layer-by-layer details. It is noted from the table that surface layers of the films have more $\mathrm{Pb}$ atoms compared to the bottom layers that have more $\mathrm{Sn}$ atoms. This suggests that the $\mathrm{SnCl}_{2}-\mathrm{PbI}_{2}$ compound films formation is divided into two; (i) the deposition of the $\mathrm{SnCl}_{2}$ layer first followed by (ii) the deposition of the $\mathrm{PbI}_{2}$. The films were deposited on a 
glass substrate, which could be simulated with a thickness and stoichiometry of $3.50 \times 10^{22}$ atoms $/ \mathrm{cm}^{2}$ and $\mathrm{Si}_{0.19} \mathrm{O}_{0.72} \mathrm{Al}_{0.05} \mathrm{Ba}_{0.04} \mathrm{As}_{0.003}$, which correlates to what was obtained by Kumar et al. [72]. Figure $2 \mathrm{~b}$ shows the compositional ratios of $\mathrm{Sn} /(\mathrm{Sn}+\mathrm{Pb})$ and $(\mathrm{Cl} / \mathrm{Cl}+\mathrm{I})$ deposited on the films. It can be observed from Figure $2 \mathrm{~b}$ that the increased amount of $\mathrm{SnCl}_{2}$ in the source boat translated to the increase in $\mathrm{Sn}$ and $\mathrm{Cl}$ atoms in the films. A similar trend is portrayed by both $\mathrm{Sn}$ and $\mathrm{Cl}$ in comparison to $\mathrm{Pb}$ and iodine, respectively. This suggests that the separation distance between the source and the substrate is within the average migration distance of the vapors.

\subsubsection{Crystal Structure and Phase Composition}

X-ray diffraction (XRD) was employed to understand the effect of the $\mathrm{SnCl}_{2}$ content on the structure of the $\mathrm{SnCl}_{2}-\mathrm{PbI}_{2}$ compound thin films. Figure 3a shows XRD patterns of $\mathrm{PbI}_{2}$ thin film, $\mathrm{SnCl}_{2}$ thin film, and $\mathrm{SnCl}_{2}-\mathrm{PbI}_{2}$ compound films as named according to the amount of $\mathrm{SnCl}_{2}$ used. On one hand, the $\mathrm{PbI}_{2}$ thin-film depicted peaks located at $2 \theta$ values of $13.05^{\circ}, 25.90^{\circ}, 39.05^{\circ}$, and $52.77^{\circ}$ assigned to (001), (011), (110), and (202) lattice planes, respectively. This $\mathrm{PbI}_{2}$ film formed a hexagonal structure, $P 321$ space group (ICSD code: 01-075-0983), with the lattice parameters, $a$ and $c$, of $4.606 \AA$ and $6.774 \AA$, respectively. On the other hand, the $\mathrm{SnCl}_{2}$ thin-film depicted peaks located at $2 \theta$ values of $14.66^{\circ}, 21.90^{\circ}$, $29.21^{\circ}, 36.64^{\circ}, 52.06^{\circ}$, and $60.14^{\circ}$ ascribed to (111), (002), (222), (132), (333), and (062) lattice planes, respectively. It turns out that the film formed is not pure $\mathrm{SnCl}_{2}$, rather hydrated tin chloride (i.e., $\left.\left[\mathrm{SnCl}_{4}\left(\mathrm{H}_{2} \mathrm{O}\right)_{2}\right] 3 \mathrm{H}_{2} \mathrm{O}\right)$ film with a monoclinic structure, $\mathrm{C} 12 / \mathrm{c} 1$ space group (COD ID: 1534841), with the lattice parameters, $a, b$ and $c$, of $7.760 \AA, 9.555 \AA$, and $4.483 \AA$, respectively [73].
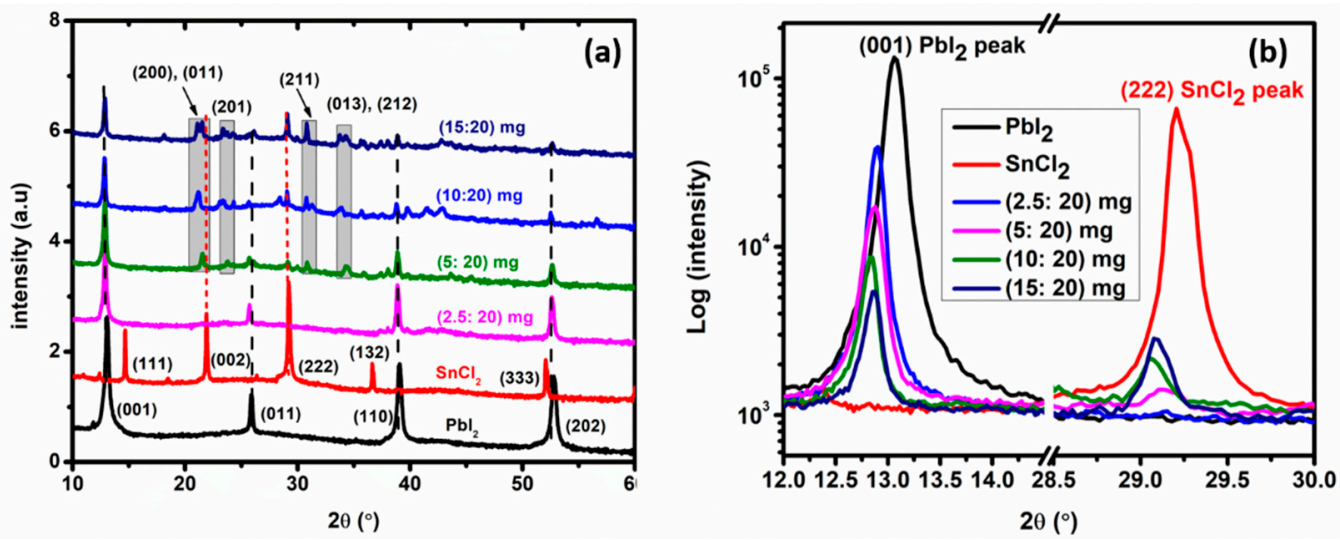

Figure 3. (a) X-ray diffraction pattern of $\mathrm{PbI}_{2}, \mathrm{SnCl}_{2}$ and mixed $\mathrm{SnCl}_{2}-\mathrm{PbI}_{2}$ compound film, (b) is the zoom-in to the (001) and (222) peaks.

It is believed that as the $\mathrm{SnCl}_{2}$ film was deposited in the chamber, it reacted with and absorbed the ambient moisture upon exposure to the environment during the transfer of the sample. For mixed $\mathrm{SnCl}_{2}-\mathrm{PbI}_{2}$ films, it is observed from Figure $3 \mathrm{a}$ that the prominent Bragg diffraction peaks correspond to that of $\left[\mathrm{SnCl}_{4}\left(\mathrm{H}_{2} \mathrm{O}\right)_{2}\right] 3 \mathrm{H}_{2} \mathrm{O}$ and $\mathrm{Pbl}_{2}$ phases, indicating mixed-phase compounds. Also, low-intensity diffraction peaks unrelated to $\left.\left[\mathrm{SnCl}_{4}\left(\mathrm{H}_{2} \mathrm{O}\right)_{2}\right] 3 \mathrm{H}_{2} \mathrm{O}\right)$ and /or $\mathrm{PbI}_{2}$ are observed for the 5, 10, and $15 \mathrm{mg} \mathrm{SnCl}_{2}$ samples. These peaks were located at $2 \theta$ values of $21.10^{\circ}, 21.52^{\circ}, 23.37^{\circ}, 30.82^{\circ}, 33.73^{\circ}$, and $34.28^{\circ}$ which were ascribed to (200), (011), (201), (211), (013), and (212) lattice planes, respectively. These peaks, which are highlighted in grey in Figure 3a belonged to tin chloride iodide (SnClI) which form an orthorhombic structure, Pnma space group (ICSD code: 01-073-0826), with the lattice parameters, $a, b$, and $c$, of $8.42 \AA, 4.43 \AA$ and $10.04 \AA$, respectively. Figure $3 b$ shows the (001) and (222) peaks of the $\mathrm{SnCl}_{2}-\mathrm{PbI}_{2}$ compound films, compared to that of $\mathrm{PbI}_{2}$ and $\mathrm{SnCl}_{2}$, respectively. It is observed in Figure $3 \mathrm{~b}$ that the intensity of the (222) peak, which corresponds to $\left[\mathrm{SnCl}_{4}\left(\mathrm{H}_{2} \mathrm{O}\right)_{2}\right] 3 \mathrm{H}_{2} \mathrm{O}$, increases as the amount of $\mathrm{Sn}$ increases in the film. The decrease in intensity of the (001) peak intensity, which corresponds to the $\mathrm{PbI}_{2}$, 
as the amount of $\mathrm{Sn}$ content increases supports the RBS discussion. Also, all the (001) peaks of $\mathrm{SnCl}_{2}-\mathrm{PbI}_{2}$ compound films shift toward lower $2 \theta$ angles with increasing $\mathrm{SnCl}_{2}$ concentration. This peak shift is due to the change in the chemical composition that could be ascribed to the chemical pressure caused by the change in lattice parameters $[74,75]$. The overall decrease in the peak intensities as the concentration of $\mathrm{Sn}$ increases suggests poor periodicity in the newly formed compound structures.

\subsubsection{Optical Properties}

The optical absorption spectra of $\mathrm{PbI}_{2}, \mathrm{SnCl}_{2}$, and the mixed $\mathrm{SnCl}_{2}-\mathrm{PbI}_{2}$ compound thin films was recorded as a function of wavelength in the range of (200-750) $\mathrm{nm}$ at room temperature, as shown in Figure 4a. The absorption onsets of the $\mathrm{SnCl}_{2}$ and $\mathrm{PbI}_{2}$ thin films were found to be at about 316 and $512 \mathrm{~nm}$, respectively [66,76-78]. Furthermore, $\mathrm{SnCl}_{2}$ thin-film depicts an absorption peak centered at about $254 \mathrm{~nm}$, while the $\mathrm{PbI}_{2}$ film depicts a characteristic absorption peak centered at about $405 \mathrm{~nm}$, featuring a shoulder at $497 \mathrm{~nm}[66,77]$. The absorption peak centered at about $252 \mathrm{~nm}$ is the contribution from the glass substrate on which the films were deposited. Generally, upon mixing $\mathrm{PbI}_{2}$ with $\mathrm{SnCl}_{2}$, an increase in the optical absorption intensity of the films in the wavelength range between $250-400 \mathrm{~nm}$ is observed, ascribed to the increase in the thickness of the films. The most noticeable feature in the optical properties of the mixed $\mathrm{SnCl}_{2}-\mathrm{PbI}_{2}$ compound thin films in comparison to that of pure $\mathrm{PbI}_{2}$ films is the red-shift of absorption onset. This necessitated the calculation of the optical band gap of the materials under investigation. The direct allowed band gap transition values were obtained by extrapolating the linear portion of the $(\alpha h v)^{2}$ versus $h v$ plot, as depicted in Figure S3 in the support information. The corresponding values of $\mathrm{E}_{\mathrm{g}}$ were found and plotted in Figure $4 \mathrm{~b}$. The $\mathrm{E}_{\mathrm{g}}$ values increase from $2.42 \mathrm{eV}$ for the $\mathrm{PbI}_{2}$ film to $3.31 \mathrm{eV}$ for the mixed $\mathrm{SnCl}_{2}-\mathrm{PbI}_{2}$ compound film (15:20 mg) as the concentration of $\mathrm{SnCl}_{2}$ increases. The increase in the $\mathrm{E}_{\mathrm{g}}$ confirms increasing concentrations of $\mathrm{Sn}$ in the films, since the $\mathrm{Eg}_{\mathrm{g}}$ of $\mathrm{SnCl}_{2}$ is $3.92 \mathrm{eV}$. This further supports and confirms the RBS and XRD results.
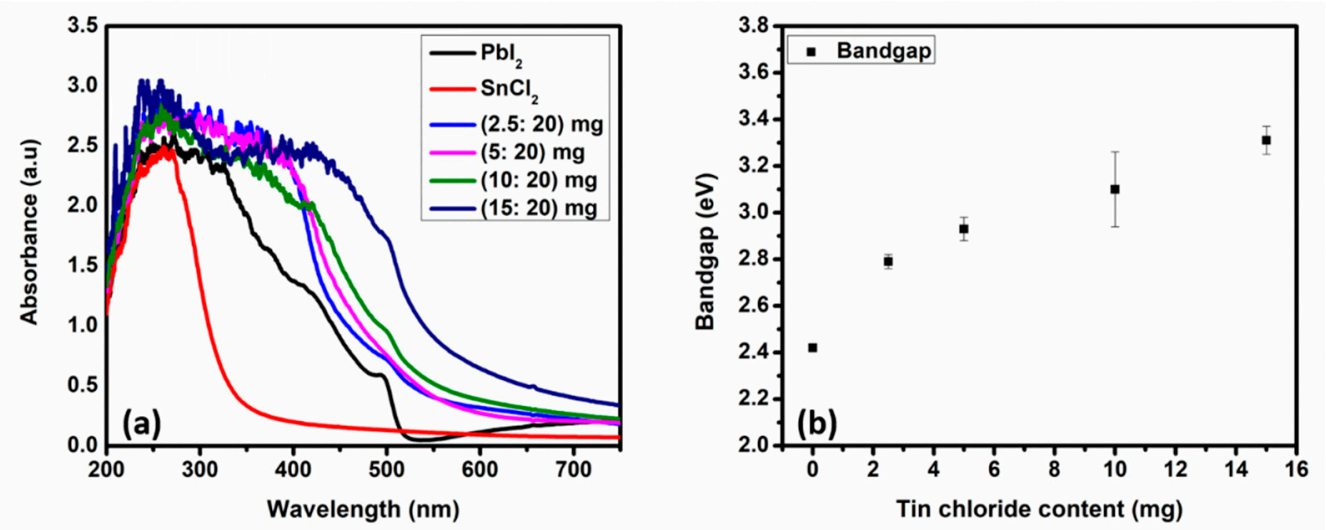

Figure 4. (a) The UV-Vis absorption spectra and (b) the $\mathrm{E}_{\mathrm{g}}$ evolution plot upon addition of the different amount of $\mathrm{SnCl}_{2}$.

\subsection{Perovskite Structure-Property Relationships}

\subsubsection{Surface Morphology}

Figure 5 shows the top view SEM images of the Pb-based, Sn-based and $\mathrm{Sn}-\mathrm{Pb}$ based perovskite films prepared using the precursor films that were discussed in the previous section. Compared with the precursor films in Figure 1, there are improvements in the grain size and surface coverage of the perovskite films. It is clear from the morphology in Figure $5 \mathrm{a}$ that $\mathrm{MAPbI}_{3}$ film is composed of well-defined, large grains $(\sim 1 \mu \mathrm{m})$ that are compact across the entire surface. The $\mathrm{MASnI}_{3}$ film is also composed of large grains, but with a porous morphology forming agglomerates, Figure $5 \mathrm{~b}$, which is due to the disorganized hydrated $\mathrm{SnCl}_{2}$ precursor film shown in Figure $1 \mathrm{~b}$. In the case of mixed 
metal-based perovskites, the crystal sizes of the films decrease as compared to the pure metal-based perovskite, Figure $5 c, d$. There is no significant difference in the surface morphology of the $\mathrm{SnCl}_{2}-\mathrm{PbI}_{2}$ compound films, except for an increased in roughness as the $\mathrm{Sn}$ concentration increases.
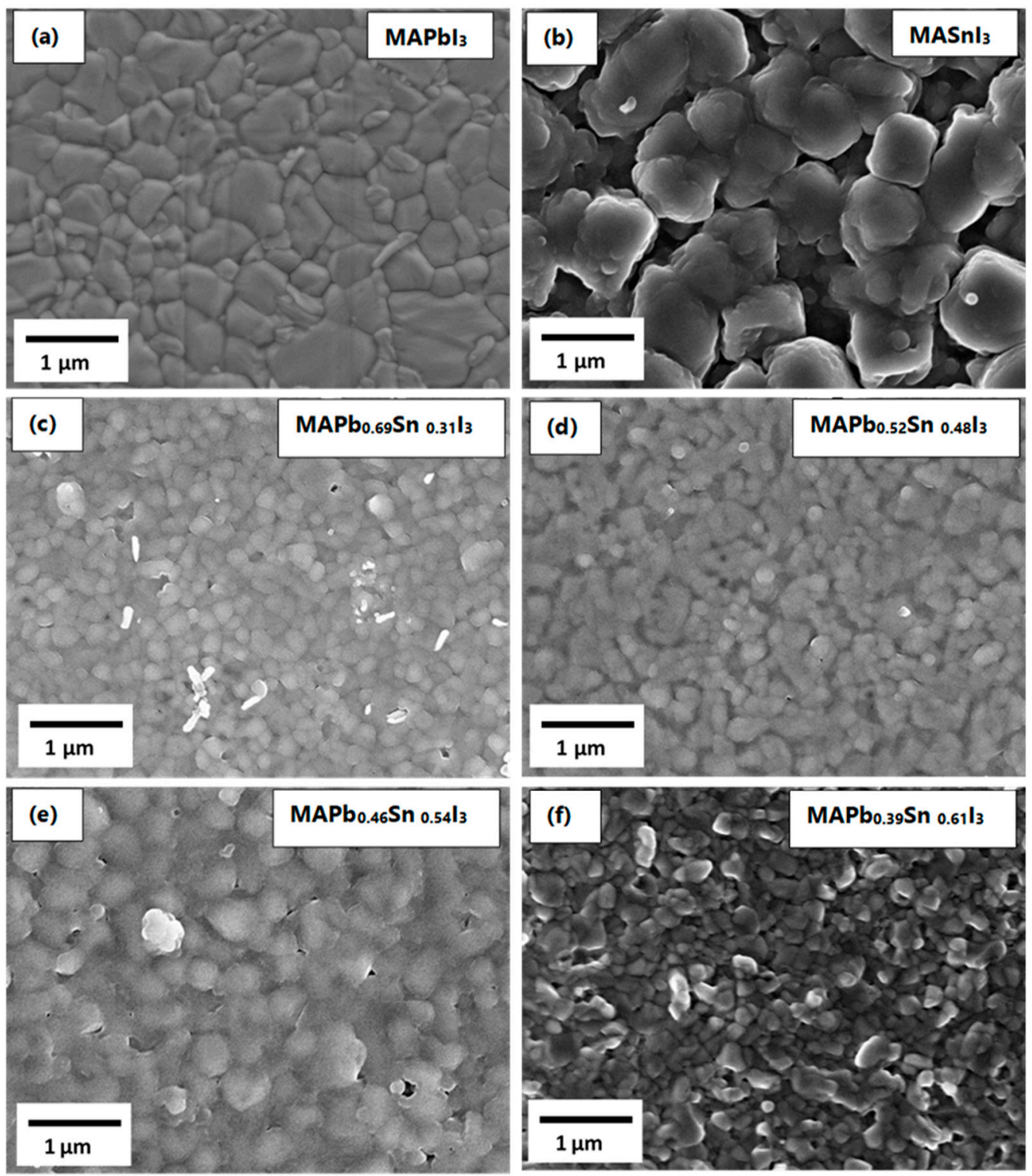

Figure 5. SEM micrographs of (a) $\mathrm{MAPbI}_{3}$ film, (b) $\mathrm{MASnI}_{3}$ films and (c-f) mixed metal-perovskites thin films.

It is worth noting that the poly-porous morphology that was observed for mixed $\mathrm{SnCl}_{2}-\mathrm{PbI}_{2}$ compound films in Figure 1, improved to become compact perovskite films composed of crystals covering the entire surface. This is attributed to the MAI penetrating through the pores leading to sufficient reaction between mixed metal halides and MAI, thus forming completely converted perovskites. It is confirmed in Figure S1b that the thickness and the roughness of the films increase as the concentration of $\mathrm{Sn}$ increases. However, a massive increase in the perovskite films is attributed to the conversion process, i.e., the exposure of the precursor films to MAI vapor at a substrate temperature of $85^{\circ} \mathrm{C}$. The thickness increased by a factor of about 1.7 from the precursor films to the perovskite films, which indicates optimum conversion parameters. 


\subsubsection{Crystal Structure and Optical Properties}

The XRD patterns of the perovskite films obtained from $\mathrm{PbI}_{2}, \mathrm{SnCl}_{2}$ and mixed $\mathrm{SnCl}_{2}$ : $\mathrm{PbI}_{2}$ compound films are shown in Figure 6a. All the perovskite films possess similar patterns in terms of peak positions with the exception of the diffraction intensities. This suggests that iodine from the MAI replaces the $\mathrm{Cl}$ in $\mathrm{SnCl}_{2}$ and mixed $\mathrm{SnCl}_{2}-\mathrm{PbI}_{2} \mathrm{com}$ pound films [79]. Also, the $\mathrm{PbI}_{2}$ stabilizes the mixed metal halide compound films and reduces their susceptibility to moisture compared to the $\mathrm{SnCl}_{2}$ film. The peaks located at $2 \theta$ values of $14.20^{\circ}, 24.57^{\circ}, 28.49^{\circ}, 31.96^{\circ}, 40.98^{\circ}, 43.30^{\circ}$, and $50.29^{\circ}$ could be ascribed to (110), (202), (220), (222), (400), (420), and (404) lattice planes, respectively. According to the crystallography open-sources database (COD), these perovskite films form a tetragonal structure with I4cm space group (COD ID: 4335638, 4335641, 4335636, for the Pb-based, mixed Sn-Pb based, and Sn-based perovskites, respectively) [80]. The $\mathrm{MAPbI}_{3}$ and $\mathrm{MAPb}_{0.69} \mathrm{Sn}_{0.31} \mathrm{I}_{3}$ show additional peaks at $12.66^{\circ}$ (denoted by an asterisk) and $58.97^{\circ}$ ascribed to $\mathrm{PbI}_{2}(001)$ and $\mathrm{MAPbI}_{3}$ (440) lattice plane, respectively. The $\mathrm{PbI}_{2}$ peak denotes slightly incomplete conversions. This could have been because of tightly packed crystals in the $\mathrm{PbI}_{2}$ and $\mathrm{Pb}_{0.24} \mathrm{Sn}_{0.11} \mathrm{I}_{0.30} \mathrm{Cl}_{0.36}$ compound films, which could limit the infusion of MAI during the conversion stage.
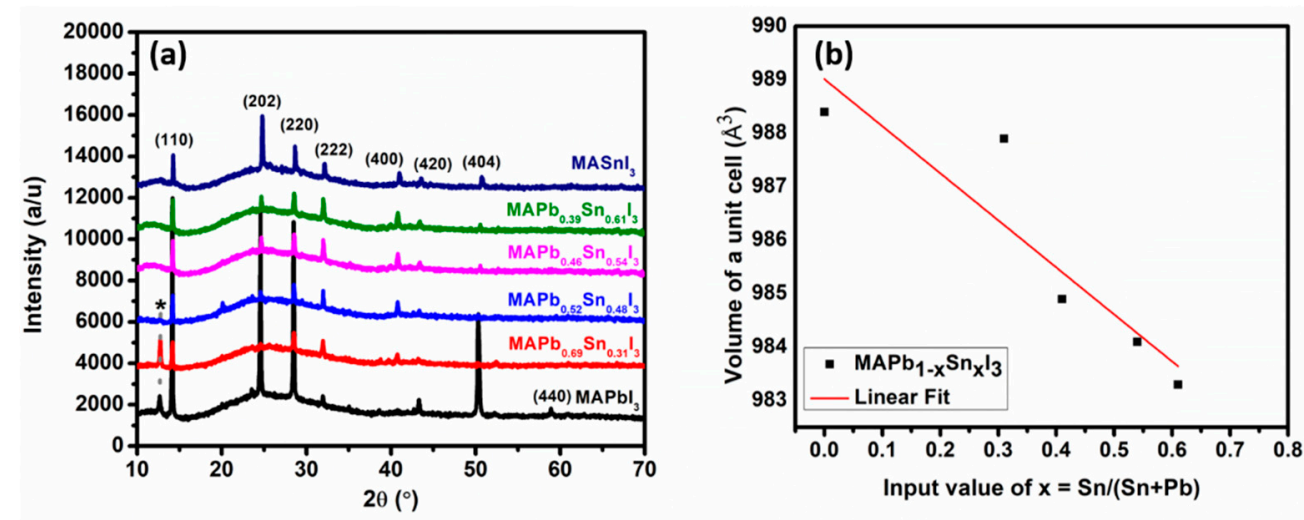

Figure 6. (a) X-ray diffraction pattern and (b) the evolution of the volume of the unit cells upon increasing content $\mathrm{Sn}$. The linear fit is used to give direction to the eye.

The highly intense $\mathrm{MAPbI}_{3}$ sample peaks are ascribed to the neat, large, and uniformly distributed crystals, while the $\mathrm{MASnI}_{3}$ sample with second-most intense peaks is ascribed only to its large crystals. The lower peak intensities of $\mathrm{MAPb}_{1-\mathrm{x}} \mathrm{Sn}_{\mathrm{x}} \mathrm{I}_{3}$ films denoted poor crystallinity of these perovskite films compared to the $\mathrm{MAPbI}_{3}$ film. Figure $6 \mathrm{~b}$ shows the inverse relation of the unit cell volume with increasing concentration of $\mathrm{Sn}$. The unit cell volume of the $\mathrm{MAPbI}_{3}$ perovskite decreases from $988.4 \AA^{3}$ to about $983.3 \AA^{3}$ upon the incorporation of $\mathrm{Sn}$ in the structure, which is coherent as the volume of the $\mathrm{MASnI}_{3}$ perovskite is $970.3 \AA^{3}$. This is due to the smaller ionic radius of Sn compared to that of $\mathrm{Pb}$. Table 2 shows the lattice constants, FWHM of (110) diffraction peak located at $2 \theta$ value of $14.2^{\circ}$ and the average crystallite size (D) estimated using Scherrer equation, $D=k \lambda / \beta \cos \theta$, where $\mathrm{k}=0.89, \lambda=0.154 \mathrm{~nm}$, and $\theta=14.3^{\circ}$ are Scherrer's constant, $X$-ray wavelength, and Bragg diffraction angle, respectively. The average crystallite size of the pure perovskites, i.e., $\mathrm{MAPbI}_{3}$ and $\mathrm{MASnI}_{3}$ are $71.9 \mathrm{~nm}$ and $65.6 \mathrm{~nm}$, respectively. These values are larger than those obtained for mixed metal perovskites as evident from Table 2. This agrees with the SEM results; considering that the pure perovskites films possessed larger grains compared to those of mixed metal perovskites. The crystallite sizes decreased upon the increasing concentration of $\mathrm{Sn}$ in the perovskite films from $71.9 \mathrm{~nm}$ for $\mathrm{MAPbI}_{3}$ to $50.9 \mathrm{~nm}$ for $\mathrm{MAPb}_{0.39} \mathrm{Sn}_{0.61} \mathrm{I}_{3}$. The crystallite size of $\mathrm{MAPb}_{0.69} \mathrm{Sn}_{0.31} \mathrm{I}_{3}$ was calculated to be $45.8 \mathrm{~nm}$, which is considered as an outlier as observed in Figure S4a. 
Table 2. Lattice constants, FWHM of (110) peak and crystallite size of perovskite films.

\begin{tabular}{cccccc}
\hline Sample & $\mathbf{a}=\mathbf{b}(\AA)$ & $\mathbf{c}(\AA)$ & Vol $\left(^{(} \AA^{3}\right)$ & FWHM () & $\begin{array}{c}\text { Crystallite } \\
\text { Size (nm) }\end{array}$ \\
\hline $\mathrm{MAPbI}_{3}$ & 8.85 & 12.62 & 988.4 & 0.1139 & 71.9 \\
$\mathrm{MAPb}_{0.69} \mathrm{Sn}_{0.31} \mathrm{I}_{3}$ & 8.83 & 12.67 & 987.9 & 0.1788 & 45.8 \\
$\mathrm{MAPb}_{0.52} \mathrm{Sn}_{0.41} \mathrm{I}_{3}$ & 8.82 & 12.66 & 984.9 & 0.1327 & 61.6 \\
$\mathrm{MAPb}_{0.46} \mathrm{Sn}_{0.54} \mathrm{I}_{3}$ & 8.82 & 12.65 & 984.1 & 0.1568 & 52.2 \\
$\mathrm{MAPb}_{0.39} \mathrm{Sn}_{0.61} \mathrm{I}_{3}$ & 8.82 & 12.64 & 983.3 & 0.1608 & 50.9 \\
$\mathrm{MASnI}_{3}$ & 8.80 & 12.53 & 970.3 & 0.1254 & 65.6 \\
\hline
\end{tabular}

The UV-Vis absorption spectra of the perovskite films are shown in Figure 7a. The $\mathrm{MAPbI}_{3}$ depicts characteristic absorption peaks centered at the wavelength of about $357 \mathrm{~nm}$ and $470 \mathrm{~nm}$ and a shoulder at $747 \mathrm{~nm}$, whereas the $\mathrm{MASnI}_{3}$ perovskite shows absorption extending from 365 to $1000 \mathrm{~nm}$ with characteristic absorption peaks centered at about 536 and $850 \mathrm{~nm}$. The absorption peak centered at about $252 \mathrm{~nm}$ is the contribution from the glass substrate on which the films were deposited. The increase in the optical absorption intensity upon the addition of $\mathrm{Sn}$ in the structure is attributed to the increase in the perovskite films thicknesses. It is noticed from Figure 7a that the absorption band edges of the films are not sharp and well-defined. This produces band tails that extend into the band gap, which increases with increasing Sn concentration that is associated with an increasing defect-concentration in the films. These band tails, also referred to as the Urbach tails, is associated with the Urbach energy $\left(E_{\mathrm{u}}\right)$ that can be extracted using the relation $\alpha=\alpha_{0} \exp \left(E / E_{u}\right)$, where $\alpha$ is the absorption coefficient and $E$ the photon energy.
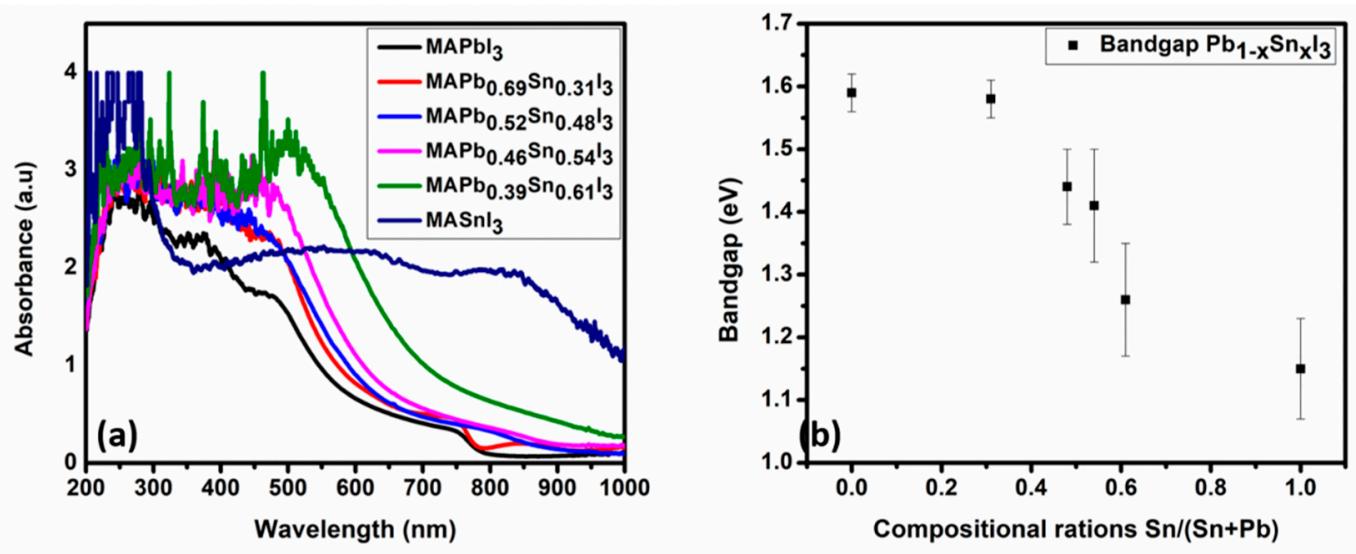

Figure 7. (a) UV-Vis absorption spectra of the perovskite films and (b) the $E_{g}$ evolution plot for different compositional ratios of $\mathrm{Sn}$. The direct allowed bandgap transition values were obtained by extrapolating the linear portion of the $(\alpha h v)^{2}$ versus $h v$ plot, as depicted in Figure S5 in the support information.

Figure $7 \mathrm{~b}$ shows the band gap $\left(\mathrm{E}_{\mathrm{g}}\right)$ evolution obtained from Tauc plots depicted in Figure S5 in the supplementary material. The incorporation of Sn decreases the band gap of the films from about $1.59 \mathrm{eV}$ for $\mathrm{MAPbI}_{3}$ to about $1.26 \mathrm{eV}$ for $\mathrm{MAPb}_{0.39} \mathrm{Sn}_{0.61} \mathrm{I}_{3}$ and the lowest $\mathrm{E}_{\mathrm{g}}$ of $1.15 \mathrm{eV}$ was obtained for $\mathrm{MASnI}_{3}$, as depicted in Figure $7 \mathrm{~b}$ and Table 3. Apart from absorption band-edge shift toward high wavelength, $\mathrm{Sn}$ incorporation also retards the structure of $\mathrm{MAPbI}_{3}$ slightly, augmented by the diminishing of $\mathrm{MAPbI}_{3}$ characteristic absorption features, which corresponds to the results in the literature [31-33,67]. However, contrary to recent studies, our results do not show absorption bandgap bowing behavior, which is the reduction of the $\mathrm{E}_{\mathrm{g}}$ of the mixed metal perovskites to values below the end compounds i.e., $\mathrm{MAPbI}_{3}(1.59 \mathrm{eV})$ and $\mathrm{MASnI}_{3}(1.15 \mathrm{eV})$ in this case. There is an ongoing debate about the origin and magnitude of the bandgap bowing in mixed metal perovskites; whether it is due to the chemical effects, structural effects, or a combination of both [81-83]. 
Nonetheless, it is believed that the $61 \%$ maximum Sn concentration employed in this study is below the bandgap bowing threshold for the deposition system and the parameters used.

Table 3. Energy Bandgap and Urbach energy of binary metal perovskites.

\begin{tabular}{ccc}
\hline Sample & Energy Bandgap (eV) & Urbach Energy (meV) \\
\hline $\mathrm{MAPbI}_{3}$ & $1.59 \pm 0.03$ & $70 \pm 10$ \\
$\mathrm{MAPb}_{0.69} \mathrm{Sn}_{0.31} \mathrm{I}_{3}$ & $1.58 \pm 0.03$ & $60 \pm 10$ \\
$\mathrm{MAPb}_{0.52} \mathrm{Sn}_{0.41} \mathrm{I}_{3}$ & $1.44 \pm 0.06$ & $220 \pm 10$ \\
$\mathrm{MAPb}_{0.46} \mathrm{Sn}_{0.54} \mathrm{I}_{3}$ & $1.41 \pm 0.09$ & $260 \pm 10$ \\
$\mathrm{MAPb}_{0.39} \mathrm{Sn}_{0.61} \mathrm{I}_{3}$ & $1.26 \pm 0.09$ & $280 \pm 60$ \\
$\mathrm{MASnI}_{3}$ & $1.15 \pm 0.08$ & $530 \pm 60$ \\
\hline
\end{tabular}

The $E_{u}$ values, which equates to the widths of the band tails of the defect states in the band gap and thus the density of disorder in the films, are tabulated in Table 3 and were obtained by plotting the natural logarithm of the absorption coefficient $\ln (\alpha)$ as a function of photon energy and then taking the reciprocal of the slope from the linear part of the curve [84,85], as shown in Figure $\mathrm{S6}$. The $\mathrm{MAPbI}_{3}$ has an $\mathrm{E}_{\mathrm{u}}$ of about $70 \mathrm{meV}$, which remains constant for the $\mathrm{MAPb}_{0.69} \mathrm{Sn}_{0.31} \mathrm{I}_{3}$ film with the lowest concentration of Sn. Further increasing the concentration of $\mathrm{Sn}$ increased the $\mathrm{E}_{\mathrm{u}}$ to about $280 \mathrm{meV}$ for $\mathrm{MAPb}_{0.39} \mathrm{Sn}_{0.61} \mathrm{I}_{3}$, and the $\mathrm{MASnI}_{3}$ showed the highest $\mathrm{E}_{\mathrm{u}}$ of about $530 \mathrm{eV}$. The increasing trend of $\mathrm{E}_{\mathrm{u}}$ with increasing concentration of $\mathrm{Sn}$ was observed by Zhao et al. and $\mathrm{Li}$ et al. $[13,86]$. This is ascribed to the increased oxygen defect centers in the thin films affiliated with the increased oxidation of $\mathrm{Sn}^{2+}$ to $\mathrm{Sn}^{4+}[13,86]$. This observation of an increasing $\mathrm{E}_{\mathrm{u}}$ with increasing $\mathrm{Sn}$ concentration confirms the XRD suggestion that the incorporation of excessive amount of $\mathrm{Sn}$ in the $\mathrm{Pb}$ based perovskites results in poor crystallization and the high-level defect density that is induced by $\mathrm{Sn}$ oxidation.

\section{Conclusions}

We synthesized mixed metal halide perovskite thin films by two step-sequential CVD, which included the deposition of mixed $\mathrm{SnCl}_{2}-\mathrm{PbI}_{2}$ compound as the precursor films and subsequently exposing them to MAI for conversion into perovskites. A controlled the concentration of $\mathrm{Sn}$ in the perovskite films was demonstrated, as quantified by RBS. The micrographs of these precursor films depicted a poly-porous surface with pores extending deep to the substrate with an increasing concentration of $S n$ in the film. These pores might have been helpful in the conversion processes in terms of acting as the passage through which MAI infiltrated the films thus leading to complete conversions into perovskites rather than partial conversions. All the perovskite films depicted similar XRD patterns corresponding to a tetragonal structure with $I 4 \mathrm{~cm}$ space group regardless of the precursor films having different crystal structures which is positive since the aim of the study was to partially replace $\mathrm{Pb}$ atoms with $\mathrm{Sn}$ without destroying the core of $\mathrm{MAPbI}_{3}$ perovskite structure. This resulted in the decrease of the unit volume of the perovskites from about 988.4 $\AA^{3}$ for $\mathrm{MAPbI}_{3}$ to about $983.3 \AA^{3}$ for $\mathrm{MAPb}_{0.39} \mathrm{Sn}_{0.61} \mathrm{I}_{3}$ which was attributed to the smaller atomic radius of $\mathrm{Sn}$ than that of $\mathrm{Pb}$. Therefore, the inclusion of $\mathrm{Sn}$ in the structure did indeed influence the properties of the resulted perovskite films manifested by the decrease in band gap from about $1.59 \mathrm{eV}$ for $\mathrm{MAPbI}_{3}$ to $1.26 \mathrm{eV}$ for $\mathrm{MAPb}_{0.39} \mathrm{Sn}_{0.61} \mathrm{I}_{3}$ and an increased defect density in the band gap that is associated with the increased oxidation of $\mathrm{Sn}^{2+}$ to $\mathrm{Sn}^{4+}$.

Supplementary Materials: The following are available online at https:/ /www.mdpi.com/article/10 $.3390 /$ ma14133526/s1, Figure S1: Thickness evolution upon different Sn compositional ratios of (a) precursor films and (b) perovskite films. It is observed from the Figure that the thickness of the film increases as the amount of Sn content increases, Figure S2: Experimental and simulated RBS spectra of (a) $\mathrm{PbI}_{2}$ thin film, and (b-e) mixed $\mathrm{SnCl}_{2}-\mathrm{PbI}_{2}$ compound thin films i.e., (2.5:20) $\mathrm{mg}$, (5:20) $\mathrm{mg}$, (10:20) $\mathrm{mg}$ and (15:20) mg, respectively. The simulated spectra in Figure S2a,b were obtained using two 
layers with a total thickness and the average stoichiometry of $3.61 \times 10^{17}$ atoms $/ \mathrm{cm}^{2}$ and $\mathrm{Pb}_{0.35} \mathrm{I}_{0.65}$ and $4.22 \& \mathrm{~Pb}_{0.24} \mathrm{Sn}_{0.11} \mathrm{I}_{0.30} \mathrm{Cl}_{0.36}$, respectively. While the spectra in Figure S2c-e were simulated using three layers with a total thickness $\left(\times 10^{17}\right.$ atoms $\left./ \mathrm{cm}^{2}\right)$ and average stoichiometry of, 4.59 $\& \mathrm{~Pb}_{0.23} \mathrm{Sn}_{0.21} \mathrm{I}_{0.11} \mathrm{Cl}_{0.43}, 4.94 \& \mathrm{~Pb}_{0.23} \mathrm{Sn}_{0.27} \mathrm{I}_{0.04} \mathrm{Cl}_{0.45}$ and $6.01 \& \mathrm{~Pb}_{0.19} \mathrm{Sn}_{0.30} \mathrm{I}_{0.02} \mathrm{Cl}_{0.48}$, respectively, Figure S3: Tauc Plots for the bandgap measurement from the UV-Vis spectra of (a) $\mathrm{PbI}_{2}$ film, (b) $\mathrm{SnCl}_{2}$ film and (c-f) mixed $\mathrm{SnCl}_{2}-\mathrm{PbI}_{2}$ compound films. The bang gaps of $\mathrm{PbI}_{2}$ and $\mathrm{SnCl}_{2}$ films were found to be $2.42 \mathrm{eV}$ and $3.92 \mathrm{eV}$, respectively. While the band gaps of mixed $\mathrm{SnCl}_{2}-\mathrm{PbI}_{2}$ compound films i.e., (2.5:20) $\mathrm{mg}$, (5:20) $\mathrm{mg}$, (10:20) $\mathrm{mg}$ and (15:20) $\mathrm{mg}$ were found to be $2.79 \mathrm{eV}, 2.93 \mathrm{eV}, 3.10 \mathrm{eV}$ and $3.31 \mathrm{eV}$, respectively, Figure S4: Crystallite size evolution upon increasing the concentration of Sn, (a) includes $\mathrm{MAPbI}_{3}$ and all the mixed metal perovskite. (b) Excludes the $45.8 \mathrm{~nm}$ average crystallite size for $\mathrm{MAPb}_{0.69} \mathrm{Sn}_{0.31} \mathrm{I}_{3}$ perovskite and includes the trendline to guide the eye, Figure S5: Tauc Plots for the bandgap measurement from the UV-Vis spectra of (a) $\mathrm{MAPbI}_{3}$ film, (b-e) mixed metal perovskite films and (f) $\mathrm{MASnI}_{3}$ film. The bang gaps of $\mathrm{MAPbI}_{3}$ and $\mathrm{MASnI}_{3}$ films were found to be $1.59 \mathrm{eV}$ and $1.15 \mathrm{eV}$, respectively. While the band gaps of mixed metal perovskite films i.e., $\mathrm{MAPb}_{0.69} \mathrm{Sn}_{0.31} \mathrm{I}_{3}$, $\mathrm{MAPb}_{0.52} \mathrm{Sn}_{0.48} \mathrm{I}_{3}, \mathrm{MAPb}_{0.46} \mathrm{Sn}_{0.54} \mathrm{I}_{3}$ and $\mathrm{MAPb}_{0.39} \mathrm{Sn}_{0.61} \mathrm{I}_{3}$ were found to be $1.58 \mathrm{eV}, 1.44 \mathrm{eV}, 1.41 \mathrm{eV}$ and $1.26 \mathrm{eV}$, respectively, Figure S6: Urbach energy approximation plots of (a) $\mathrm{MAPbI}_{3}$ film, (b-e) mixed metals perovskite films and (f) $\mathrm{MASnI}_{3}$ film. The Urbach energies of $\mathrm{MAPbI}_{3}$ and $\mathrm{MASnI}_{3}$ films were found to be $0.07 \mathrm{eV}$ and $0.53 \mathrm{eV}$, respectively. While the Urbach energies of mixed metal perovskite films i.e., $\mathrm{MAPb}_{0.69} \mathrm{Sn}_{0.31} \mathrm{I}_{3}, \mathrm{MAPb}_{0.52} \mathrm{Sn}_{0.48} \mathrm{I}_{3}, \mathrm{MAPb}_{0.46} \mathrm{Sn}_{0.54} \mathrm{I}_{3}$ and $\mathrm{MAPb}_{0.39} \mathrm{Sn}_{0.61} \mathrm{I}_{3}$ were found to be $0.06 \mathrm{eV}, 0.22 \mathrm{eV}, 0.26 \mathrm{eV}$ and $0.28 \mathrm{eV}$, respectively.

Author Contributions: Conceptualization, C.J.A. and S.S.M.; methodology, S.S.M., S.N.; software, C.J.A.; validation, C.J.A., S.N. and A.S.B.; formal analysis, S.S.M.; investigation, S.S.M.; resources, C.J.A.; data curation, F.C. and C.M.; writing-original draft preparation, S.S.M.; writing-review and editing, S.S.M.; visualization, S.S.M., C.J.A. and S.N.; supervision, C.J.A. and A.S.B.; project administration, C.J.A.; funding acquisition, C.J.A. All authors have read and agreed to the published version of the manuscript.

Funding: The authors would like to acknowledge the South African National Research Foundation (NFR) (Grant No: 117874, 103621, 92520 and 93212) and Armaments Corporation of South Africa (ARMSCOR), DESUP project, for financial support.

Institutional Review Board Statement: Not applicable.

Informed Consent Statement: Not applicable.

Data Availability Statement: The data that support the findings of this study are available from the corresponding author, upon reasonable request.

Conflicts of Interest: The authors declare no conflict of interest.

\section{References}

1. Wenk, H.; Bulakh, A. Minerals: Their constitution and origin. Can. Min. J. 2004, 125, 7.

2. Kojima, A.; Teshima, K.; Shirai, Y.; Miyasaka, T. Organometal halide perovskites as visible-light sensitizers for photovoltaic cells. J. Am. Chem. Soc. 2009, 131, 6050-6051. [CrossRef] [PubMed]

3. Podolsky, B.; Rosen, N.; Clauser, J.F.; Steinberg, A.M.; Chiao, R.Y.; Vaziri, A.; Weihs, G.; Zeilinger, A.; Bennink, R.S.; Bentley, S.J.; et al. Efficient Hybrid Solar Cells Based on Meso-Superstructured Organometal Halide Perovskites. Science 2012, 338, $643-648$.

4. Burschka, J.; Pellet, N.; Moon, S.J.; Humphry-Baker, R.; Gao, P.; Nazeeruddin, M.K.; Grätzel, M. Sequential deposition as a route to high-performance perovskite-sensitized solar cells. Nature 2013, 499, 316-319. [CrossRef]

5. Liu, M.; Johnston, M.B.; Snaith, H.J. Efficient planar heterojunction perovskite solar cells by vapour deposition. Nature 2013, 501, 395-398. [CrossRef]

6. Jeon, N.J.; Noh, J.H.; Kim, Y.C.; Yang, W.S.; Ryu, S.; Seok, S. Il Solvent engineering for high-performance inorganic-organic hybrid perovskite solar cells. Nat. Mater. 2014, 13, 897-903. [CrossRef]

7. Green, M.A.; Ho-Baillie, A.; Snaith, H.J. The emergence of perovskite solar cells. Nat. Photonics 2014, 8, 506-514. [CrossRef]

8. Yang, W.S.; Park, B.W.; Jung, E.H.; Jeon, N.J.; Kim, Y.C.; Lee, D.U.; Shin, S.S.; Seo, J.; Kim, E.K.; Noh, J.H.; et al. Iodide management in formamidinium-lead-halide-based perovskite layers for efficient solar cells. Science 2017, 356, 1376-1379. [CrossRef]

9. Chan, S.H.; Chang, Y.H.; Wu, M.C. High-performance perovskite solar cells based on low-temperature processed electron extraction layer. Front. Mater. 2019, 6, 1-7. [CrossRef]

10. Frolova, L.A.; Davlethanov, A.I.; Dremova, N.N.; Zhidkov, I.; Akbulatov, A.F.; Kurmaev, E.Z.; Aldoshin, S.M.; Stevenson, K.J.; Troshin, P.A. Efficient and stable $\mathrm{MAPbI}_{3}$-based perovskite solar cells using polyvinylcarbazole passivation. J. Phys. Chem. Lett. 2020, 11, 6772-6778. [CrossRef] [PubMed] 
11. Shockley, W.; Queisser, H.J. Detailed balance limit of efficiency of p-n junction solar cells. J. Appl. Phys. 1961, 32, 510-519. [CrossRef]

12. Im, J.; Stoumpos, C.C.; Jin, H.; Freeman, A.J.; Kanatzidis, M.G. Antagonism between spin-orbit coupling and steric effects causes anomalous band gap evolution in the perovskite photovoltaic materials $\mathrm{CH}_{3} \mathrm{NH}_{3} \mathrm{Sn}_{1-\mathrm{x}} \mathrm{Pb}_{\mathrm{x}} \mathrm{I}_{3}$. J. Phys. Chem. Lett. 2015, 6, 3503-3509. [CrossRef]

13. Zhao, B.; Abdi-Jalebi, M.; Tabachnyk, M.; Glass, H.; Kamboj, V.S.; Nie, W.; Pearson, A.J.; Puttisong, Y.; Gödel, K.C.; Beere, H.E.; et al. High open-circuit voltages in tin-rich low-bandgap perovskite-based planar heterojunction photovoltaics. Adv. Mater. 2017, 29. [CrossRef]

14. Kazim, S.; Nazeeruddin, M.K.; Grätzel, M.; Ahmad, S. Perovskite as light harvester: A game changer in photovoltaics. Angew. Chem. Int. Ed. 2014, 53, 2812-2824. [CrossRef]

15. Paquin, F.; Rivnay, J.; Salleo, A.; Stingelin, N.; Silva, C. Multi-phase semicrystalline microstructures drive exciton dissociation in neat plastic semiconductors. J. Mater. Chem. C 2015, 3, 10715-10722. [CrossRef]

16. Serrano-lujan, L.; Espinosa, N.; Larsen-olsen, T.T.; Abad, J.; Urbina, A.; Krebs, F.C. Tin- and lead-based perovskite solar cells under scrutiny: An environmental perspective. Adv. Energy Mater. 2015, 15, 1-5. [CrossRef]

17. Stranks, S.D.; Nayak, P.K.; Zhang, W.; Stergiopoulos, T.; Snaith, H.J. Formation of thin films of organic-inorganic perovskites for high-efficiency solar cells. Angew. Chem. Int. Ed. 2015, 54, 3240-3248. [CrossRef] [PubMed]

18. Chen, Y.; He, M.; Peng, J.; Sun, Y.; Liang, Z. Structure and growth control of organic-inorganic halide perovskites for optoelectronics: From polycrystalline films to single crystals. Adv. Sci. 2016, 3. [CrossRef] [PubMed]

19. Hoefler, S.F.; Trimmel, G.; Rath, T. Progress on lead-free metal halide perovskites for photovoltaic applications: A review. Mon. Chem. 2017, 148, 795-826. [CrossRef]

20. Stroyuk, O. Lead-free hybrid perovskites for photovoltaics. Beilstein J. Nanotechnol. 2018, 9, 2209-2235. [CrossRef]

21. Liu, C.; Li, W.; Fan, J.; Mai, Y. A brief review on the lead element substitution in perovskite solar cells. J. Energy Chem. 2018, 27, 1054-1066. [CrossRef]

22. Zhou, D.; Zhou, T.; Tian, Y.; Zhu, X.; Tu, Y. Perovskite-based solar cells: Materials, methods, and future perspectives. J. Nanomater. 2018, 2018. [CrossRef]

23. Zhang, Q.; Hao, F.; Li, J.; Zhou, Y.; Wei, Y.; Lin, H. Perovskite solar cells: Must lead be replaced-and can it be done? Sci. Technol. Adv. Mater. 2018, 19, 425-442. [CrossRef]

24. Ansari, M.I.H.; Qurashi, A.; Nazeeruddin, M.K. Frontiers, opportunities, and challenges in perovskite solar cells: A critical review. J. Photochem. Photobiol. C Photochem. Rev. 2018, 35, 1-24. [CrossRef]

25. Jena, A.K.; Kulkarni, A.; Miyasaka, T. Halide perovskite photovoltaics: Background, status, and future prospects. Chem. Rev. 2019, 119, 3036-3103. [CrossRef]

26. Ke, W.; Kanatzidis, M.G. Prospects for low-toxicity lead-free perovskite solar cells. Nat. Commun. 2019, 1-4. [CrossRef]

27. Ji, D.; Wang, S.; Zhang, H.; Wang, H.; Zhang, B.; Zhang, C.; Li, X. Why cannot all divalent cations completely substitute the Pb cations of $\mathrm{CH}_{3} \mathrm{NH}_{3} \mathrm{PbI}_{3}$ perovskite? Phys. Lett. 2019, 383, 2130-2138. [CrossRef]

28. Wang, K.; Subhani, W.S.; Wang, Y.; Zuo, X.; Wang, H.; Duan, L.; Liu, S. Metal cations in efficient perovskite solar cells: Progress and perspective. Adv. Mater. 2019, 31,1-17. [CrossRef]

29. Liu, C.; Li, W.; Li, H.; Zhang, C.; Fan, J.; Mai, Y. C60 additive-assisted crystallization in $\mathrm{CH}_{3} \mathrm{NH}_{3} \mathrm{~Pb}_{0.75} \mathrm{Sn}_{0.25} \mathrm{I}_{3}$ perovskite solar cells with high stability and efficiency. Nanoscale 2017, 9, 13967-13975. [CrossRef] [PubMed]

30. Leijtens, T.; Prasanna, R.; Gold-Parker, A.; Toney, M.F.; McGehee, M.D. Mechanism of tin oxidation and stabilization by lead substitution in tin halide perovskites. ACS Energy Lett. 2017, 2, 2159-2165. [CrossRef]

31. Gu, S.; Lin, R.; Han, Q.; Gao, Y.; Tan, H.; Zhu, J. Tin and mixed lead-tin halide perovskite solar cells: Progress and their application in tandem solar cells. Adv. Mater. 2020, 32, 1-16. [CrossRef]

32. Ogomi, Y.; Morita, A.; Tsukamoto, S.; Saitho, T.; Fujikawa, N.; Shen, Q.; Toyoda, T.; Yoshino, K.; Pandey, S.S.; Ma, T.; et al. $\mathrm{CH}_{3} \mathrm{NH}_{3} \mathrm{Sn}_{\mathrm{x}} \mathrm{Pb}_{(1-\mathrm{x})} \mathrm{I}_{3}$ perovskite solar cells covering up to $1060 \mathrm{~nm}$. J. Phys. Chem. Lett. 2014, 5, 1004-1011. [CrossRef] [PubMed]

33. Hao, F.; Stoumpos, C.C.; Chang, R.P.H.; Kanatzidis, M.G. Anomalous band gap behavior in mixed Sn and Pb perovskites enables broadening of absorption spectrum in solar cells. J. Am. Chem. Soc. 2014, 136, 8094-8099. [CrossRef] [PubMed]

34. Yang, Z.; Rajagopal, A.; Chueh, C.; Jo, S.B.; Liu, B.; Zhao, T.; Jen, A.K. Stable low-bandgap Pb-Sn binary perovskites for tandem solar cells. Adv. Mater. 2016, 28, 8990-8997. [CrossRef]

35. Calvo, M.E.; Hagfeldt, A. Optical analysis of $\mathrm{CH}_{3} \mathrm{NH}_{3} \mathrm{Sn}_{\mathrm{x}} \mathrm{Pb}_{1-\mathrm{x}} \mathrm{I}_{3}$ absorbers: A roadmap for perovskite-on-perovskite tandem solar cells. J. Mater. Chem. A 2016. [CrossRef]

36. Eperon, G.E.; Leijtens, T.; Bush, K.A.; Prasanna, R.; Green, T.; Wang, J.T.W.; McMeekin, D.P.; Volonakis, G.; Milot, R.L.; May, R.; et al. Perovskite-perovskite tandem photovoltaics with optimized band gaps. Science 2016, 354, 861-865. [CrossRef]

37. Liu, X.; Yang, Z.; Chueh, C.C.; Rajagopal, A.; Williams, S.T.; Sun, Y.; Jen, A.K.Y. Improved efficiency and stability of Pb-Sn binary perovskite solar cells by Cs substitution. J. Mater. Chem. A 2016, 4, 17939-17945. [CrossRef]

38. Zhu, L.; Yuh, B.; Schoen, S.; Li, X.; Aldighaithir, M.; Richardson, B.J.; Alamer, A.; Yu, Q. Solvent-molecule-mediated manipulation of crystalline grains for efficient planar binary lead and tin triiodide perovskite solar cells. Nanoscale 2016, 8, 7621-7630. [CrossRef] [PubMed]

39. Rajagopal, A.; Yang, Z.; Jo, S.B.; Braly, I.L.; Liang, P.W.; Hillhouse, H.W.; Jen, A.K.Y. Highly Efficient perovskite-perovskite tandem solar cells reaching $80 \%$ of the theoretical limit in photovoltage. Adv. Mater. 2017, 29, 1-10. [CrossRef] [PubMed] 
40. Tang, Z.K.; Xu, Z.F.; Zhang, D.Y.; Hu, S.X.; Lau, W.M.; Liu, L.M. Enhanced optical absorption via cation doping hybrid lead iodine perovskites. Sci. Rep. 2017, 7, 1-7. [CrossRef] [PubMed]

41. Zhu, H.L.; Xiao, J.; Mao, J.; Zhang, H.; Zhao, Y.; Choy, W.C.H. Controllable crystallization of $\mathrm{CH}_{3} \mathrm{NH}_{3} \mathrm{Sn}_{0.25} \mathrm{~Pb}_{0.75} \mathrm{I}_{3} \mathrm{perovskites}$ for hysteresis-free solar cells with efficiency reaching 15.2\%. Adv. Funct. Mater. 2017, 27. [CrossRef]

42. Zong, Y.; Wang, N.; Zhang, L.; Ju, M.G.; Zeng, X.C.; Sun, X.W.; Zhou, Y.; Padture, N.P. Homogenous alloys of formamidinium lead triiodide and cesium tin triiodide for efficient ideal-bandgap perovskite solar cells. Angew. Chem. Int. Ed. 2017, 56, 12658-12662. [CrossRef]

43. Li, L.; Zhang, F.; Hao, Y.; Sun, Q.; Li, Z.; Wang, H.; Cui, Y.; Zhu, F. High efficiency planar Sn-Pb binary perovskite solar cells: Controlled growth of large grains via a one-step solution fabrication process. J. Mater. Chem. C 2017, 5, 2360-2367. [CrossRef]

44. Li, Y.; Sun, W.; Yan, W.; Ye, S.; Rao, H.; Peng, H.; Zhao, Z. 50\% Sn-based planar perovskite solar cell with power conversion efficiency up to $13.6 \%$. Adv. Energy Mater. 2016, 6, 1-7. [CrossRef]

45. Lyu, M.; Zhang, M.; Cooling, N.A.; Jiao, Y.; Wang, Q.; Yun, J.H.; Vaughan, B.; Triani, G.; Evans, P.; Zhou, X.; et al. Highly compact and uniform $\mathrm{CH}_{3} \mathrm{NH}_{3} \mathrm{Sn}_{0.5} \mathrm{~Pb}_{0.5} \mathrm{I}_{3}$ films for efficient panchromatic planar perovskite solar cells. Sci. Bull. 2016, 61, 1558-1562. [CrossRef]

46. Zuo, F.; Williams, S.T.; Liang, P.; Chueh, C.; Liao, C.; Jen, A.K. Binary-metal perovskites toward high-performance planarheterojunction hybrid solar cells. Adv. Mater. 2014, 26, 6454-6460. [CrossRef]

47. Lin, G.; Lin, Y.; Huang, H.; Cui, R.; Guo, X.; Liu, B.; Dong, J.; Guo, X.; Sun, B. Novel exciton dissociation behavior in tin-lead organohalide perovskites. Nano Energy 2016, 27, 638-646. [CrossRef]

48. Zhao, D.; Yu, Y.; Wang, C.; Liao, W.; Shrestha, N.; Grice, C.R.; Cimaroli, A.J.; Guan, L.; Ellingson, R.J.; Zhu, K.; et al. Low-bandgap mixed tin-lead iodide perovskite absorbers with long carrier lifetimes for all-perovskite tandem solar cells. Nat. Energy 2017, 2, 17018. [CrossRef]

49. Tsai, C.M.; Wu, H.P.; Chang, S.T.; Huang, C.F.; Wang, C.H.; Narra, S.; Yang, Y.W.; Wang, C.L.; Hung, C.H.; Diau, E.W.G. Role of tin chloride in tin-rich mixed-halide perovskites applied as mesoscopic solar cells with a carbon counter electrode. ACS Energy Lett. 2016, 1, 1086-1093. [CrossRef]

50. Liu, C.; Fan, J.; Li, H.; Zhang, C.; Mai, Y. Highly efficient perovskite solar cells with substantial reduction of lead content. Sci. Rep. 2016, 6, 1-8. [CrossRef] [PubMed]

51. Kapil, G.; Ripolles, T.S.; Hamada, K.; Ogomi, Y.; Bessho, T.; Kinoshita, T.; Chantana, J.; Yoshino, K.; Shen, Q.; Toyoda, T.; et al. Highly efficient $17.6 \%$ tin-lead mixed perovskite solar cells realized through spike structure. Nano Lett. 2018, 18, 3600-3607. [CrossRef]

52. Jiang, T.; Chen, Z.; Chen, X.; Chen, X.; Xu, X.; Liu, T.; Bai, L.; Yang, D.; Di, D.; Sha, W.E.I.; et al. Power conversion efficiency enhancement of low-bandgap mixed $\mathrm{Pb}$-Sn perovskite solar cells by improved interfacial charge transfer. ACS Energy Lett. 2019, 4, 1784-1790. [CrossRef]

53. Li, C.; Song, Z.; Zhao, D.; Xiao, C.; Subedi, B.; Shrestha, N.; Junda, M.M.; Wang, C.; Jiang, C.S.; Al-Jassim, M.; et al. Reducing saturation-current density to realize high-efficiency low-bandgap mixed tin-lead halide perovskite solar cells. Adv. Energy Mater. 2019, 9, 1-9. [CrossRef]

54. Xu, X.; Chueh, C.C.; Yang, Z.; Rajagopal, A.; Xu, J.; Jo, S.B.; Jen, A.K.Y. Ascorbic acid as an effective antioxidant additive to enhance the efficiency and stability of $\mathrm{Pb} / \mathrm{Sn}$-based binary perovskite solar cells. Nano Energy 2017, 34, 392-398. [CrossRef]

55. Yun, Y.; Cho, J.Y.; Heo, J.; Lee, S. Fabrication of MASnI 3 and $\mathrm{MASn}_{\mathrm{x}} \mathrm{Pb}_{(1-\mathrm{x})} \mathrm{I}_{3}$ thin films by conversion from SnS thin film. Appl. Sci. Converg. Technol. 2018, 27, 169-172. [CrossRef]

56. Ke, W.; Spanopoulos, I.; Tu, Q.; Hadar, I.; Li, X.; Shekhawat, G.S.; Dravid, V.P.; Kanatzidis, M.G. Ethylenediammonium-based "hollow" $\mathrm{Pb} / \mathrm{Sn}$ perovskites with ideal band gap yield solar cells with higher efficiency and stability. J. Am. Chem. Soc. 2019, 141, 8627-8637. [CrossRef]

57. Du, X.; Qiu, R.; Zou, T.; Chen, X.; Chen, H.; Zhou, H. Enhanced uniformity and stability of Pb-Sn perovskite solar cells via $\mathrm{Me}_{4} \mathrm{NBr}$ passivation. Adv. Mater. Interfaces 2019, 6, 1-7. [CrossRef]

58. Tong, J.; Song, Z.; Kim, D.H.; Chen, X.; Chen, C.; Palmstrom, A.F.; Ndione, P.F.; Reese, M.O.; Dunfield, S.P.; Reid, O.G.; et al. Carrier lifetimes of $>1 \mathrm{~ms}$ in Sn-Pb perovskites enable efficient all-perovskite tandem solar cells. Science 2019, 364, 475-479. [CrossRef]

59. Lian, X.; Chen, J.; Zhang, Y.; Qin, M.; Li, J.; Tian, S.; Yang, W.; Lu, X.; Wu, G.; Chen, H. Highly efficient Sn/Pb binary perovskite solar cell via precursor engineering: A two-step fabrication process. Adv. Funct. Mater. 2019, 29, 1-9. [CrossRef]

60. Klug, M.T.; Milot, R.L.; Milot, R.L.; Patel, J.B.; Green, T.; Sansom, H.C.; Farrar, M.D.; Ramadan, A.J.; Martani, S.; Wang, Z.; et al. Metal composition influences optoelectronic quality in mixed-metal lead-tin triiodide perovskite solar absorbers. Energy Environ. Sci. 2020, 13, 1776-1787. [CrossRef]

61. Li, C.; Song, Z.; Chen, C.; Xiao, C.; Subedi, B.; Harvey, S.P.; Shrestha, N.; Subedi, K.K.; Chen, L.; Liu, D.; et al. Low-bandgap mixed tin-lead iodide perovskites with reduced methylammonium for simultaneous enhancement of solar cell efficiency and stability. Nat. Energy 2020, 5, 768-776. [CrossRef]

62. Chen, Z.; Liu, M.; Li, Z.; Shi, T.; Yang, Y.; Yip, H.L.; Cao, Y. Stable Sn/Pb-based perovskite solar cells with a coherent 2D/3D interface. iScience 2018, 9, 337-346. [CrossRef] [PubMed] 
63. Ke, W.; Chen, C.; Spanopoulos, I.; Mao, L.; Hadar, I.; Li, X.; Hoffman, J.M.; Song, Z.; Yan, Y.; Kanatzidis, M.G. Narrow-bandgap mixed lead/tin-based 2D Dion-Jacobson perovskites boost the performance of solar cells. J. Am. Chem. Soc. 2020, 142, 15049-15057. [CrossRef] [PubMed]

64. Ngqoloda, S.; Arendse, C.J.; Muller, T.F.; Miceli, P.F.; Guha, S.; Mostert, L.; Oliphant, C.J. Air-stable hybrid perovskite solar cell by sequential vapor deposition in a single reactor. ACS Appl. Energy Mater. 2020, 3, 2350-2359. [CrossRef]

65. Pammi, S.V.N.; Lee, H.W.; Eom, J.H.; Yoon, S.G. Predominant stable $\mathrm{MAPbI}_{3}$ films deposited via chemical vapor deposition: Stability studies in illuminated and darkened states coupled with temperature under an open-air atmosphere. ACS Appl. Energy Mater. 2018, 1, 3301-3312. [CrossRef]

66. Wu, Y.; Islam, A.; Yang, X.; Qin, C.; Liu, J.; Zhang, K.; Peng, W.; Han, L. Retarding the crystallization of $\mathrm{PbI}_{2}$ for highly reproducible planar-structured perovskite solar cells via sequential deposition. Energy Environ. Sci. 2014, 7, 2934-2938. [CrossRef]

67. Wei, H.; Tang, Y.; Feng, B.; You, H. Importance of $\mathrm{PbI}_{2}$ morphology in two-step deposition of $\mathrm{CH}_{3} \mathrm{NH}_{3} \mathrm{PbI}_{3}$ for high-performance perovskite solar cells. Chin. Phys. B 2017, 26. [CrossRef]

68. Moreno-Romero, P.M.; Corpus-Mendoza, A.N.; Millán-Franco, M.A.; Rodríguez-Castañeda, C.A.; Torres-Herrera, D.M.; Liu, F.; $\mathrm{Hu}, \mathrm{H}$. Roughness and structural modification of $\mathrm{PbI}_{2}$ thin films by isopropanol treatment to improve methylammonium lead halide formation and solar cell efficiency. J. Mater. Sci. Mater. Electron. 2019, 30, 17491-17503. [CrossRef]

69. Félix, R.; Llobera-Vila, N.; Hartmann, C.; Klimm, C.; Hartig, M.; Wilks, R.G.; Bär, M. Preparation and in-system study of SnCl 2 precursor layers: Towards vacuum-based synthesis of Pb-free perovskites. RSC Adv. 2018, 8, 67-73. [CrossRef]

70. Popov, G.; Mattinen, M.; Hatanpää, T.; Vehkamäki, M.; Kemell, M.; Mizohata, K.; Räisänen, J.; Ritala, M.; Leskelä, M. Atomic Layer Deposition of $\mathrm{PbI}_{2}$ Thin Films. Chem. Mater. 2019, 31, 1101-1109. [CrossRef]

71. Tsevas, K.; Smith, J.A.; Kumar, V.; Rodenburg, C.; Fakis, M.; Mohd Yusoff, A.R.b.; Vasilopoulou, M.; Lidzey, D.G.; Nazeeruddin, M.K.; Dunbar, A.D.F. Controlling $\mathrm{PbI}_{2}$ Stoichiometry during Synthesis to Improve the Performance of Perovskite Photovoltaics. Chem. Mater. 2021. [CrossRef]

72. Kumar, S.; Kumar, S.; Dixit, P.N.; Rauthan, C.M.S.; Sharma, R. Composition of glass substrates, an important consideration for depositing adherent diamond-like carbon films. J. Mater. Sci. Lett. 2000, 19, 2055-2057. [CrossRef]

73. Shihada, A.F.; Abushamleh, A.S.; Weller, F. Crystal structures and raman spectra of tin complexes 1-4 (see abstract). Zeitschrift Anorg. Allg. Chem. 2004, 630, 841-847. [CrossRef]

74. King, H.W. Quantitative size-factors for metallic solid solutions. J. Mater. Sci. 1966, 1, 79-90. [CrossRef]

75. Cordero, Z.C.; Schuh, C.A. Phase strength effects on chemical mixing in extensively deformed alloys. Acta Mater. 2015, 82, 123-136. [CrossRef]

76. Bafna, M.; Garg, N. Investigation of Optical Properties of Tin Chloride $\left(\mathrm{SnCl}_{2}\right)$ Doped Poly Methyl Methacrylate (PMMA) Composite Films. IIS Univ. J. Sci. Technol. 2017, 6, 27-32.

77. Zhu, X.; Wangyang, P.; Sun, H.; Yang, D.; Gao, X.; Tian, H. Facile growth and characterization of freestanding single crystal $\mathrm{PbI}_{2}$ film. Mater. Lett. 2016, 180, 59-62. [CrossRef]

78. Ghosh, T.; Bandyopadhyay, S.; Roy, K.K.; Kar, S.; Lahiri, A.K.; Maiti, A.K.; Goswami, K. Optical and structural properties of lead iodide thin films prepared by vacuum evaporation method. Cryst. Res. Technol. 2008, 43, 959-963. [CrossRef]

79. Ngqoloda, S.; Arendse, C.J.; Guha, S.; Muller, T.F.; Klue, S.C.; Magubane, S.S.; Oliphant, C.J. Mixed-halide perovskites solar cells through $\mathrm{PbICl}$ and $\mathrm{PbCl}_{2}$ precursor films by sequential chemical vapor deposition. Sol. Energy 2021, 215, 179-188. [CrossRef]

80. Stoumpos, C.C.; Malliakas, C.D.; Kanatzidis, M.G. Semiconducting tin and lead iodide perovskites with organic cations: Phase transitions, high mobilities, and near-infrared photoluminescent properties. Inorg. Chem. 2013, 52, 9019-9038. [CrossRef]

81. Goyal, A.; McKechnie, S.; Pashov, D.; Tumas, W.; Van Schilfgaarde, M.; Stevanović, V. Origin of Pronounced Nonlinear Band Gap Behavior in Lead-Tin Hybrid Perovskite Alloys. Chem. Mater. 2018, 30, 3920-3928. [CrossRef]

82. Rajagopal, A.; Stoddard, R.J.; Hillhouse, H.W.; Jen, A.K.Y. On understanding bandgap bowing and optoelectronic quality in $\mathrm{Pb}-\mathrm{Sn}$ alloy hybrid perovskites. J. Mater. Chem. A 2019, 7, 16285-16293. [CrossRef]

83. Parrott, E.S.; Green, T.; Milot, R.L.; Johnston, M.B.; Snaith, H.J.; Herz, L.M. Interplay of Structural and Optoelectronic Properties in Formamidinium Mixed Tin-Lead Triiodide Perovskites. Adv. Funct. Mater. 2018, 28, 1-11. [CrossRef]

84. Boubaker, K. A physical explanation to the controversial urbach tailing universality. Eur. Phys. J. Plus 2011, 126, 1-4. [CrossRef]

85. Sun, H.; Zhu, X.; Yang, D.; Yang, J.; Gao, X.; Li, X. Morphological and structural evolution during thermally physical vapor phase growth of $\mathrm{PbI}_{2}$ polycrystalline thin films. J. Cryst. Growth 2014, 405, 29-34. [CrossRef]

86. Li, N.; Zhu, Z.; Li, J.; Jen, A.K.Y.; Wang, L. Inorganic CsPb ${ }_{1-x} \mathrm{Sn}_{\mathrm{x}} \mathrm{IBr}_{2}$ for Efficient Wide-Bandgap Perovskite Solar Cells. Adv. Energy Mater. 2018, 8, 1-8. [CrossRef] 